\title{
Supply chain environmental R\&D cooperation and product performance: Exploring the network dynamics of positional embeddedness
}

\author{
M. Cristina De Stefano ${ }^{a, *}$, María J. Montes-Sancho ${ }^{\mathrm{b}}$ \\ ${ }^{a}$ Department of Organization Engineering, Business Administration and Statistics, ETSII, Universidad Politécnica de Madrid, C/ José Gutiérrez Abascal 2, Madrid, Spain \\ ${ }^{\mathrm{b}}$ Department of Business Administration, Universidad Carlos III de Madrid, C/ Madrid, 126, Getafe, Madrid, Spain
}

\section{A R T I C L E I N F O}

\section{Keywords:}

Sustainability

Sourcing

Embeddedness

Innovation

Collaboration

Supply network

\begin{abstract}
A B S T R A C T
Companies increasingly need to work with their partners to address sustainability issues, but benefits from environmental R\&D cooperation can be limited by the complexity of its management. This paper examines how the interplay between dyadic and network relationships can contribute to increase the success of environmental R\&D cooperation. Using secondary data, we examine whether the positional embeddedness in the supply network structure of partners engaged in environmental R\&D cooperation amplifies the effects of cooperation on product performance. Non-monotonic effects of environmental R\&D cooperation and embeddedness are also tested. The results indicate that the positional embeddedness of partners triggered by multiple sourcing strategy amplifies the effects of environmental R\&D cooperation on product environmental performance. The interaction effects become however insignificant in the presence of increasing complexity and excessive environmental R\&D cooperation.
\end{abstract}

\section{Introduction}

Innovation and collaboration have become key means of integrating sustainability into supply chain management (SCM). Firms with innovation capabilities and managerial orientation towards sustainability are able to overcome constraints because they can identify and take advantage of the abilities and skills of a number of actors in the supply chain (Pagell and Wu, 2009). Additionally, collaboration plays an important role in significantly reducing the uncertainty of innovation and the overall costs (Beske and Seuring, 2014). Developing environmental innovation requires firms to invest in knowledge and technologies, which are predominantly positioned outside their traditional frame of competence. Hence, companies need to cooperate with partners whose knowledge and complementary competencies can reduce uncertainty and effectively carry out the development of the innovation required to satisfy sustainability requirements (Oh and Rhee, 2008; Zacharia et al., 2011).

The innovation literature has extensively demonstrated the importance of R\&D cooperation for innovation development (e.g. Coleman and Burt, 2000; Beers and Zand, 2013; Agostini and Caviggioli, 2015; Un and Asakawa, 2015). In the area of sustainability, De Marchi (2012) shows that R\&D cooperation, and specifically cooperation with suppliers, is even more important for environmental innovation than for other types of innovation. However, recent studies have cast some doubt on the effectiveness of R\&D cooperation in specific circumstances. In particular, some researchers have identified possible drawbacks that can reduce the beneficial effects of R\&D cooperation on innovation outcomes (e.g. Caner and Tyler, 2015; Gesing et al., 2015; Wang and Li-ying, 2015; Hottenrott and Lopes-Bento, 2016). Although there has been substantial progress in this area, the understanding of the factors that can amplify or undermine the environmental R\&D cooperation benefits on performance is still limited.

In the sustainable SCM literature, researchers have provided some insights that begin to open up this issue (Fawcett et al., 2015; Touboulic and Walker, 2015). They suggest that the management of supply chain collaboration for environmental innovation can be difficult and complex (Min et al., 2005; Oh and Rhee, 2008; Pagell and Wu, 2009; Cao and Zhang, 2011). Firms need to not only have the technology to handle innovation, but also sufficient logistical and organizational capabilities to ensure its efficient production (Vachon and Klassen, 2007; Oh and Rhee, 2008; Aláez-Aller and Longás-García, 2010). Hence, the success of environmental R\&D cooperation can rely on the willingness of partners to integrate external capabilities (Fawcett et al., 2015) and restructure their processes (Nair et al., 2016) to effectively carry out innovation development. Only in this way can organizations capitalize on the benefits from $R \& D$ cooperation.

To advance this emerging stream of research, we argue that increasing benefits in buyer-supplier environmental R\&D cooperation are

\footnotetext{
* Corresponding author.

E-mail address: mcristina.destefano@upm.es (M.C. De Stefano).
} 
rooted in the supply netw ork structure and, specifically, on h ow partners are positionally embedded in the supply network. Starting from the perspective that the shape of the supply network structure is defined by the dominant buying companies' sourcing strategy, we suggest that the way in which buyer-supplier dyad relationships are jointly positionally embedded in the supply netw ork can contribute to generate collaborative dynamics that amplify the effects of $R$ \&D c ooperation on performance.

This study focuses on the automotive industry which, although it has been extensively analysed, continues to be of great interest for researchers as shown by several recent studies on R\&D and supply chain netw ork (Agostini and Caviggioli, 2015; Brandenburg, 2016; Jasiński et al., 2016). In this study, the automotive industry is an ideal setting because it is heavily affected by the n eed to r eorient $\mathrm{i}$ ts business to$\mathrm{w}$ ards a greener approach (Penna and Geels, 2015). Practitioners and academics argue that the strategic priority of firms in this sector is to invest in R\&D activities to produce low -carbon products (Pricew aterhouseCoopers, 2007; KPMG, 2010; Minin et al., 2010; Zapata and Nieuw enhuis, 2010; Rothenberg and Levy, 2012). One strategy to achieve this objective is to increase cooperation with supply chain partners (Leohold and Hodac, 2009; Engau and Hoffmann, 2011), since suppliers now manufacture almost 70\% of a car (Wilhelm, 2011), $\mathrm{w}$ hich moves 'upstream' the locus of innovation in this sector (Rothenberg and Ettlie, 2011). Consequently, the engagement of suppliers and buying companies in R\&D cooperation and their interconnection in the supply netw ork structure plays a key role in wellintegrated product production planning and $\mathrm{R} \& \mathrm{D}$ road mapping to reduce the carbon impact of vehicles. In this study, w e focus on relationships betw een focal firms a nd their fi rst-tier su ppliers (i .e. the upstream relationships) and on the netw ork relationships among firsttier suppliers.

This paper contributes to the literature in SCM by analyzing whether the interaction betw een dyadic relationships and supply network structure contributes to increasing the success of environmental R\&D cooperation. Most of the emerging studies that attempt to understand the role of the network structure on innovation output only focus on the position that a company or a dyad occupies in the netw ork structure and analyse its effect on innovation performance (Polidoro et al., 2011; Bellamy et al., 2014; Roscoe et al., 2016). Other studies, on the other hand, have raised the importance to assess interactions betw een netw ork and dyadic dynamics (Choi and Wu, 2009; Pathak et al., 2014). How ever, research in this field is still theoretical-based or constrained by qualitative methods (Dubois and Fredriksson, 2008; Wilhelm, 2011; Nair et al., 2016). This study contributes in this incipient area of research by extending this perspective. By bringing insights from relational theory (Dyer and Singh, 1998) and netw ork theory literature (Granovetter, 1985), w e build a theoretically-based discussion on supply chain cooperation and its interaction $\mathrm{w}$ ith the supply chain structure. The relational view encompasses the idea that competitive advantages derive from specialized networks or idiosyncratic inter-firm relationships betw een trading partners, w hereas netw ork theory analyses the partners of ties in a netw ork as set of nodes and ties. We also advance the empirical research on sustainable SCM by complementing and generalizing case studies that have been, the primary methods of data collections in the field so far (Kim et al., 2011; Ashby et al., 2012). Additionally, since sustainable supply chains can be often technology related and different performance measurements need to be developed for different industries (Hassini et a l., 2012; T aticchi et a 1., 2013), we seek to respond to the call for more industry-specific s tudies (Hassini et al., 2012). For this reason, we have considered a period in which the automotive industry experienced considerable technological and regulatory uncertainty due to having to reduce carbon emissions from cars.

The rest of the paper is structured as follow s. In Section 2, we provide an overview of the literature on sustainable SCM and collaboration. In Section 3, w e develop the conceptual model and hypotheses based on the relational view perspective and the supply network structure literature. In Section 4, measures, data and estimation method are described. Results from testing the hypotheses are shown in Section 5. Finally, in Section 6, we discuss the findings and limitations of the study, offering some guidelines for future research.

\section{Sustainability in supply chain management}

An important issue that emerges from the literature on sustainable SCM is that incorporating sustainability into supply chains introduces complexity in the management of those chains (Abbasi and Nilsson, 2012). Sustainability requires supply chain practices to change and be managed in a different way (Beske and Seuring, 2014), and managers need to rethink their strategic relationships as a whole to accommodate these changes (Pagell et al., 2010; Touboulic and Walker, 2015), as competitive advantage depends on successful supply chain management (Lee, 2011). Barriers in implementing sustainable supply chains involve high costs of coordination due to poor communication in the supply chain (Seuring and Müller, 2008), lack of visibility of the whole upstream and downstream tiers (Acquaye et al., 2014), as well as problems linked with the management of a wide variety of environmental metrics to control the overall supply chain (Bai, 2012; Hassini et al., 2012).

Studies have attributed a key role to suppliers in addressing sustainability in SCM (Geffen and Rothenberg, 2000; Klassen and Vachon, 2003; Vachon and Klassen, 2006a, 2007; Jayaraman et al., 2007; Pagell et al., 2007; Simpson et al., 2007; Delmas and Montiel, 2009; Gattiker and Carter, 2010; Simpson, 2010). Given its importance, a variety of methods to select and assess suppliers for 'greening the supply chain' have been debated (Chiou et al., 2011; Caniëls et al., 2013; Govindan et al., 2015), highlighting the tendency of focal companies to pass on the pressures 'to do something about sustainability' to suppliers (Seuring and Müller, 2008).

Researchers have also analysed collaboration as a key initiative between a focal company and its suppliers to achieve sustainability (Vachon and Klassen, 2006b, 2008). Collaboration in SCM means that "two or more independent companies work jointly to plan and execute operations with greater success than when acting in isolation" (Simatupang and Sridharan, 2002). Thus, the rationale behind collaboration is an alignment of partners' interests so that all supply chain actors can obtain greater benefits from working together than alone (Paulraj et al., 2008). Most studies that have analysed collaboration suggest the importance of the "nature" of supply chain relationships to obtain benefits from collaboration (Paulraj et al., 2008; Ambrose et al., 2010; Lettice et al., 2010; Nyaga et al., 2010; Zacharia et al., 2011). Here, the relational view (Dyer and Singh, 1998) has been one of the most successfully applied approaches in SCM (Chen and Paulraj, 2004a, 2004b), helping to build and analyse instruments that enable effective supply chain collaborations (Fawcett et al., 2008; Cao and Zhang, 2010, 2011). This theory has allowed to explain why there are so few cases in which supply chain collaborations are really effective (Fawcett et al., 2008) and to enhance collaboration performance (Vurro et al., 2009; Paulraj, 2011; Touboulic and Walker, 2015). However, some new literature suggests that supply chain collaborative behaviours can depend on the network structure wherein supply chain partners are embedded (Nair et al., 2018), which has important implications for environmental innovation development and diffusion of environmental practices (Tate et al., 2013; Nair et al., 2016). In this study, our rationale is to extend the relational view with insights from network theory related to positional embeddedness.

\section{Conceptual framework and hypothesis development}

\subsection{A relational and network view of collaborative supply chains}

Moving away from the characteristics of arm's-length market relationships, the relational view (Dyer and Singh, 1998) strongly 
emphasizes that idiosyncratic inter-firm relationships as a c ause of relational rents. It postulates that idiosyncratic inter-firm relationships can be created when partners: 1 ) invest in relation-specific a ssets; 2 ) exchange substantial know ledge, including know ledge that results in joint learning; 3) combine complementary resources or capabilities to create unique new products, services, or technologies; and 4) reduce transaction costs. Idiosyncratic inter-firm $r$ elationships, $t$ hus, would lead to relational rents and, in turn, to competitive advantages.

This approach even indicates some other mechanisms in the relationship that $\mathrm{w}$ ould amplify the effects of i diosyncratic inter-firm relationships on the rent generation. For instance, Dyer and Singh (1998) posit that specific absorptive capacity and incentive alignments betw een partners increase the potential of generating relational rents through know ledge sharing. They also highlight the importance of having access to information and resources to obtain greater relational rents. How ever, studies that have applied the relational view either in SCM or in R\&D literature have been strictly focused on analyzing how specific $\mathrm{c}$ haracteristics of $\mathrm{p}$ artners $\mathrm{s}$ uch a s d egree of $\mathrm{i}$ nnovation, diversification o $\mathrm{r}$ i ntegration a ffect pe rformance. In ot her $\mathrm{w}$ ords, the analysis of amplifying effects has been limited. Additionally, although the relational view refers implicitly to the importance of the position that companies in a relationship occupy in a netw ork, it does not directly take into account this variable as an enabling mechanism to amplify the relational rents of collaboration.

In this study, we combine the relational view with network theory and in particular with the embeddedness approach (Granovetter, 1985; Choi and Kim, 2008) to understand how a particular position in a network of partners can work as a mechanism to amplify the relational rents of cooperation. With the term embeddedness, Granovetter (1985) contextualizes the economic behaviour of actors in a social structure. In particular, positional embeddedness captures the role or the relative importance that actors have in a system (Borgatti and Everett, 1992), $\mathrm{w}$ hich go beyond proximate direct and indirect ties (Freeman, 1978; Everett and Borgatti, 1999). It indicates the centrality of an organization as the sum of connections to others, w eighting the centrality of these other companies (Bonacich, 1987; Gulati and Gargiulo, 1999).

\section{2. $R \& D$ cooperation and product environmental performance}

In line with the relational view, R\&D cooperation turns out to be an important organizational solution to achieve competitive advantages in contexts characterized by rapid technological change (Miotti and Sachwald, 2003). It is a form of technological collaboration in which companies voluntarily agree to jointly carry out research and development on a specific t echnology (Chiesa a nd M anzini, 1 998). Especially, when the level of technological uncertainty is high, as in the case of environmental innovation (Oh and Rhee, 2008; De Marchi, 2012), companies prefer recurring to R\&D cooperation in order to have access to both closely complementary and dissimilar activities (Bougrain and Haudeville, 2002) as well as to the expertise that cannot be generated in-house (Becker and Dietz, 2004). R\&D cooperation, therefore, enables firms t o e xploit p artners' r esources, t echnologies ( Teece, 1 992; Baum et al., 2000), and know-how (Belderbos et al., 2004; Fritsch and Franke, 2004); thereby enhancing learning capabilities (Kleinknecht and Reijnen, 1992; Becker and Dietz, 2004).

A number of studies have provided compelling empirical evidence that R\&D cooperation, especially $w$ ith suppliers, positively influences innovation outcomes (Becker and Dietz, 2004; Faems et al., 2005; Santamaria and Surroca, 2011; Un and Asakaw a, 2015). R\&D cooperation involves ‘balanced know ledge integration' betw een a buyer and a supplier with a high level of joint decision-making that facilitates innovation (Revilla and Villena, 2012). Suppliers can contribute to reducing technological uncertainty (Robertson and Gatignon, 1998) and market risks related to the introduction of new technologies (Singh, 1997; Oh and Rhee, 2008; Wong et al., 2011). They can also provide information and expertise regarding new ideas and technology
(Takeishi, 2001), anticipate potential problems (Ragatz et al., 2002), invest in appropriate equipment and tools to minimize errors (Koufteros et al., 2007; Song and Di Benedetto, 2008; Un and Asakawa, 2015), and as a result contribute to smoothing the innovation process. Regarding sustainability, researchers have also recognized the key role of suppliers in triggering the development of environmental innovation (Geffen and Rothenberg, 2000; Vachon and Klassen, 2008; De Marchi, 2012) and in enhancing the buyer's environmental performance (Vachon and Klassen, 2006b; Albino et al., 2012). Suppliers are important due to the deep knowledge that they have about the architecture of the buyers' production processes and products, which can facilitate environmental innovation development (Vachon and Klassen, 2006a).

Environmental innovation requires firms to restructure or "create new processes, techniques, practices, systems and products to avoid or reduce environmental harms" (cfr. De Marchi, 2012, p. 615). While different levels of environmental innovation (incremental or radical) can be distinguished (Hart, 1995; Hellström, 2007), this type of innovation involves the uncertainty related to the introduction of a new generation of technologies (Tushman and Anderson, 1986; Pisano, 1990; Stock and Tatikonda, 2000; Magnusson and Berggren, 2001). The development of new technologies implies the acceptance of risks related to making existing technologies obsolete (Robertson and Gatignon, 1998) and risks associated with "green irreversible mistakes" that potentially can lead to business failure (Shing, 1997; Pinkse and Kolk, 2010). Additionally, organizations have low incentives to invest in environmental innovation due to its 'double externality problem' (De Marchi, 2012; Stucki and Woerter, 2012). This means that companies are generally unable to exclusively obtain benefit from the value created by investments in environmental innovation due to the public nature of knowledge, which can benefit other firms, and because inevitably society captures a part of benefits (De Marchi, 2012; Stucki and Woerter, 2012). Taken together, technological uncertainty and double externality problems can, therefore, delay the development of environmental innovation and firms need to cooperate with strategic suppliers to offset this effect.

The literature has widely debated these issues, especially in connection to the automotive industry (Levy and Rothenberg, 2002; Lee, 2011; Rothenberg and Ettlie, 2011; Penna and Geels, 2015). In this sector, technological uncertainty and its associated costs have been exacerbated by the slow response of consumers to green products (Dijk and Yarime, 2010; Pinkse and Kolk, 2010; Dijk et al., 2013) and the complexity of the production system (Morgan and Daniels, 2001; Dietl et al., 2009; Christensen, 2011). For all these reasons, in Europe, the European Commission has been sensitive about pushing for the reduction of carbon emissions from new cars and in fact, waited until 2009 before introducing mandatory carbon regulation for passenger cars (EC 443/2009).

Recent studies, specifically developed in the context of the automotive industry, also suggest the need to focus R\&D cooperation in environmental area. In particular, they link the possibility of producing low-carbon vehicles to the production of alternative and radical powertrain systems for cars (Zapata and Nieuwenhuis, 2010). These technologies require companies to modify their patent portfolio by incorporating environmental innovation (Penna and Geels, 2015; Borgstedt et al., 2017). Specialization in this type of innovation could provide the knowledge needed to manage the multiple and radical powertrain systems emerging in the industry (Sierzchula et al., 2012), as well as the trade-offs that characterize these technologies, which in turn affect performance (Pinkse and Kolk, 2010; De Stefano et al., 2016). Although companies are specializing their innovations in the environmental area, it has been shown that incremental environmental innovation can be insufficient to reduce carbon emission from vehicles, and radical or combined (radical and incremental) innovations are needed for this purpose (De Stefano et al., 2016). This means that companies need to specialize in environmental innovation to learn about the different types of technologies, as well as to acquire the 
know ledge needed to balance and combine different types of environmental innovations in order to reduce carbon emissions.

In line with these insights, other researchers argue that radical innovation, like alternative pow ertrain systems, cannot be developed $\mathrm{w}$ ithout the cooperation of suppliers. Both incumbent and new suppliers play a pivotal role in the innovation process because they possess a specific and u nique know ledgeb ase (Roscoe et a l., 2016; Borgstedt et al., 2017). Hence, we suggest that buyers and suppliers need to engage in environmental $\mathrm{R} \& \mathrm{D}$ cooperation to promote the technological transition of the products, as generic R\&D cooperation is insufficient to meet this aim:

Hypothesis 1a. Buyer-supplier environmental $R \& D$ cooperation fosters the production of low-carbon products.

\subsection{Curvilinear effects of environmental $R \& D$ cooperation}

The R\&D literature also show s that the relationship betw een $R \& D$ cooperation and performance can be non-monotonic. High engagement in R\&D cooperation might be the cause of decreasing marginal benefits on product performance. Studies have put forward various reasons that seek to explain this type of relationship, such as the risk of opportunistic behaviour, coordination problems, as well as transaction and disclosure costs (Hottenrott and Lopes-Bento, 2016). In a context of technological uncertainty, an inverted U-shape relationship betw een intense R\&D cooperation and performance might be due to delays in the capacity of partners to absorb and apply unfamiliar technology know ledge to products (Lin et al., 2012).

Research suggests that for developing environmental innovations, buyers need to cooperate $\mathrm{w}$ ith both incumbent and new suppliers (Roscoe et al., 2016; Borgstedt et al., 2017). On the one hand, cooperation betw een a buyer and incumbent suppliers can be easy to coordinate due to the technology overlaps existing among partners, which could facilitate knowledge transfer (Oxley and Sampson, 2004; Kavusan et al., 2016). On the other, this type of cooperation might be insufficient to drive radical in novations an d consequently outstanding environmental results (Birkinshaw et al., 2007; Johnsen, 2011). According to Vasudeva (2011), increasing cooperation $\mathrm{w}$ ith partners whose technological approaches overlap can increase the redundancy of ideas, skill sets and know ledge, and thereby reduce the benefits of cooperation. Thus, after a certain point, the possibilities of combining existing capabilities in an innovative $\mathrm{w}$ ay might be limited and exhausted (Vasudeva and Anand, 2011), and path dependencies that aim to reinforce the status quo might severely undermine the likelihood of obtaining significant innovation changes (Lin et al., 2012). Hence, excessive cooperation with incumbent suppliers may result in decreasing marginal effects on product environmental performance.

Cooperation with new suppliers has a greater potential to promote radical innovations (Roscoe et al., 2016). How ever, decreasing marginal benefits $\mathrm{m}$ ight a lso o ccur b ecause this c ooperation $\mathrm{c}$ an b e characterized by increasing communication costs due to the probable technological distance existing between a buyer and new suppliers (Lin et al., 2012). In line with Nooteboom et al. (2007) insights, w e posit that when a buyer cooperates with a new supplier, it is likely that at the beginning the cognitive distance betw een them is so large as to preclude the sufficient mutual understanding needed to ca pitalize on the benefits of cooperation. Thus, partners need time to help each other to 'stretch and connect' their diverse knowledge as well as assimilate the knowledge produced from R\&D cooperation. Furthermore, when partners are engaged in cooperation for new technological development, the knowledge is uncoded and difficult to transfer (Kotabe an d Swan, 1995; Hoetker, 2005; Kotabe et al., 2003). These aspects, together with the the lower levels of synergies and shared experiences with partners (Vasudeva and Anand, 2011), can slow and complicate the learning process, reducing the utilization of know ledge produced from R\&D cooperation. Hence, increasing cooperation with new suppliers in the short term might not be useful to internalize knowledge, resulting in marginal benefits for product environmental performance.

By combining these two sets of arguments, we suggest that increasing cooperation with both incumbent and new suppliers can, up to a point, produce benefits in the production of a low-carbon product. After that, an excessive cooperation with both are characterized by multiple trade-offs that reduce the benefits of cooperation on the production of low-carbon products:

Hypothesis 1b. There is an inverted U-shaped relationship between increasing buyer-supplier environmental $R \& D$ cooperation and the production of low-carbon products.

\subsection{Sourcing strategy and supply network structure}

The present work also posits that partners can capitalize on greater benefits from R\&D cooperation depending on their network structure. According to Fawcett et al. (2015), collaboration to pursue new capabilities always produces resistance because it requires substantive changes in the organizational structure of most companies involved in the supply chain. In order to obtain greater relational rents from cooperation, firms have to integrate their internal capabilities with their partners' capabilities by making significant intra-organizational investments (Zacharia et al., 2011; Whipple et al., 2015). Greater integration of partners' production knowledge increases their combinative competitive capabilities ${ }^{1}$ (Lii and Kuo, 2016), resulting in effective supply chain collaboration (Fawcett et al., 2008; Cao and Zhang, 2010, 2011) and greater advantages for both buyer and suppliers' performance (Vachon and Klassen, 2007; Paulraj et al., 2008; Ambrose et al., 2010; Lettice et al., 2010; Nyaga et al., 2010; Zacharia et al., 2011).

In the modeling on how the environmental innovation emerge, Nair et al. (2016) note the importance of the structuring process to formalize the development of innovation. They suggest that the structuring process is dominated by buying focal firms, which revise the procedures and routines of their first tier-suppliers. Next, through supply networks, buyers propagate and amplify the vision of developing environmental innovations in the extended network (Nair et al., 2016). In the same line, Roscoe et al. (2016), argue that buyers also have to strategically manage different typologies of supply networks with their first-tier suppliers to improve sustainability performance.

The literature shows that sourcing strategies are a powerful tool in the focal company's hands to affect network structure and its dynamics. The buyer's strategic decision to purchase parts of a product from a single supplier or from multiple suppliers has implications not only at the level of a specific dyadic relationship but also at network level (Ford and McDowell, 1999; Dubois and Fredriksson, 2008; Munksgaard, 2010). Researchers have also found that buyers that decide to buy groups of similar components from multiple suppliers promote positive network dynamics because they affect the strength of relationships with their first-tier suppliers and the interconnections among first-tier suppliers simultaneously (Dubois and Fredriksson, 2008; Aláez-Aller and Longás-García, 2010; Roseira et al., 2010). At level of buyer-supplier dyad, information and knowledge sharing become more intense because the level of competition among suppliers over the same component increases (Dubois and Fredriksson, 2008; Wilhelm, 2011). At the same time, suppliers that deliver the same components to the buyer become mutually interdependent and therefore cooperate more to improve the supplied components (Dubois and Fredriksson, 2008; Wilhelm, 2011).

Through multiple sourcing strategy, therefore, focal companies shape their supply network structures, which activate the dynamics that

\footnotetext{
1 "Combinative competitive capabilities" are defined as a manufacturer's capacity to provide superior quality, delivery, and flexibility at a low cost" (Lii and Kuo, 2016).
} 
facilitate the introduction of innovations driven by a specific buyersupplier relationship involved in $R \& D$ cooperation. It can happen that other first-tier s uppliers of the s ame component a re willing to a dopt a new innovation quickly in order to avoid exclusion from the buyer's portfolio. In other words, the buyer does not need to act as a broker to push innovation in the supply chain. The interconnections of first-tier suppliers that deliver the same component promote the development of capabilities that spread the innovation throughout the supply chain (Aláez-Aller and Longás-García, 2010; Wu et al., 2010).

\subsubsection{Positional embeddedness}

By extending the arguments proposed by previous studies (Nair et al., 2016; Roscoe et al., 2016), w e suggest that the position that partners involved in environmental R\&D cooperation have in the net$\mathrm{w}$ ork structure is critical to understanding the mechanisms that can increase the effects of $R \& D$ c ooperation on p erformance. T he w ay in which dyadic buyer-supplier relationships are embedded in extended netw orks can influence the l evel of c ollaboration in the relationship. This is because the $\mathrm{w}$ ay in $\mathrm{w}$ hich partners are interconnected in a netw ork can generate informational, reputational and social benefits that help companies to mitigate 'collaboration hazards' (Polidoro et al., 2011). For instance, Vurro et al. (2009) link collaborative supply chain relationships to high supply chain density (i.e. increasing interactions betw een the actors in the supply chain), and to high centrality of the focal company (i.e. its relative position $w$ ithin the netw ork), finding that both density and centrality facilitate know ledge flow a nd ease communication betw een partners.

In a netw ork structure $w$ here suppliers share the delivery of the same components, w e specifically p ostulate t hat b uyer-supplier R\&D cooperation can amplify their effects on performance if partners occupy a central position in the netw ork structure. Studies show that the combined centrality (or positional embeddedness) of two partners in a netw ork structure provides them the possibility to access valuable information and the appropriate resources, which would make effective, reliable and stable the level of collaboration in the cooperation (Gulati and Gargiulo, 1999; Ahuja, 2000; Polidoro et al., 2011). In R\&D cooperation, partners $\mathrm{w}$ ith positional embeddedness in the network structure also promote working collaborations because they have experience at managing multiple ties. Thus, they are able to move quickly in identifying new projects and funneling them inside the organization (Pow ell et al., 1996), which transforms them into highly reliable and competent collaborations. In these terms, positional embeddedness in the network structure of buyer-supplier dyads can amplify the effects of cooperation on performance.

Futhermore, the way in which dyadic buyer-supplier relationships are embedded in the netw ork structure can also affect the diffusion of know ledge produced through R\&D cooperation on other members of the supply chain. Recently, Tate et al. (2013) have associated the widespread diffusion of environmental business practices to a high level of relational and structural embeddedness (Granovetter, 1985). Therefore, the benefits from dyadic buyer-supplier R\&D c ooperation c an be boosted in the context of particular netw ork structures. As central partners manage multiple tiers and as, in turn, these tiers can be connected with several other ties (Bonacich, 1987), positional embeddedness dyads have therefore the advantage not only of having access to information but also the pow er to spread information throughout the netw ork structure. In R\&D cooperation, if buyer-supplier dyads are positionally embedded in the netw ork structure, they have greater control in propagating the idea of adopting environmental innovation across supply netw orks and can even impose certain behaviour patterns. In other words, positionally embedded partners not only receive valuable information from the netw ork that is useful to increase cooperation results, but their position also provides the pow er to diffuse the know ledge created in the cooperation across the netw ork, amplifying in this way the effect of cooperation on performance. As suggested by Ahuja et al. (2009), the most decentralized companies or companies with low centrality tend to collaborate with highly centralized companies in order to improve their position in the network. Hence, buyersupplier dyads with strong positional embeddedness can encourage mimetic behaviours from the most decentralized first-tier suppliers. This latter group might adopt environmental innovation in order to improve their position in the network and avoid exclusion from the buyer's portfolio; amplifying in this way the overall effects of buyersupplier R\&D cooperation on performance:

Hypothesis 2a. Buyer-supplier positional embeddedness (combined supply network centrality) amplifies the effects of environmental $R \& D$ cooperation on the production of low-carbon products.

Whereas the positional embeddedness of partners in the supply network structure can boost benefits resulting from collaboration, increasing environmental R\&D cooperation with partners highly embedded in the supply network structure may provide decreasing marginal benefits on performance. Ahuja et al. (2009) indicate that increasing cooperation with highly embedded partners may lead to redundant information. In particular, when partners need to master a new technology, cooperation with peripheral partners that manage these technologies might be desirable in terms of performance (Gulati and Gargiulo, 1999). Extending these arguments in our context, this implies that increasing environmental R\&D cooperation between a buyer and a supplier that is highly embedded in the network structure may undermine the possibility of accessing new knowledge and the technology needed to develop environmental innovation, thereby generating decreasing marginal effects on performance. This is possibly because increasing R\&D cooperation with highly embedded partners involves in most cases incumbent suppliers, and they are likely to be more central than new entry suppliers. Hence, increasing R\&D cooperation with highly embedded suppliers might provide a redundant and insufficient knowledge base, which may in turn further undermine improvements in environmental performance.

Hypothesis 2b. Buyer-supplier positional embeddedness (combined supply network centrality) amplifies the effects of environmental $R \& D$ cooperation on the production of low-carbon products up to a threshold, after which if environmental $R \& D$ cooperation increases, the moderation effect is reduced.

\subsubsection{Complexity}

Another relevant issue in this field is the management of supply network complexity. From a structural perspective, the supply chain is a network of firms that directly and indirectly are engaged in the manufacturing and assembly of parts to create a finished product (Choi et al., 2001; Choi and Hong, 2002). According to Choi and Hong (2002), when a product relies on a large number of parts, complexity in the supply network tends to increase because the number of relationships between a focal company and suppliers grows; and hence the efforts to consolidate these relationships (Choi and Hong, 2002). Complexity in the supply chain network therefore increases with the number and variety of members in each tier (horizontal complexity), with the number of tiers (vertical complexity), and/or the geographic distance between a focal firm and its suppliers (spatial complexity) (Choi and Hong, 2002). Structural complexity often involves operational complexity, which is related to the growing interactions between the members of the network and to the variety of interdependent behaviours (Bozarth et al., 2009; Bode and Wagner, 2015).

According to recent literature, complex supply networks will inevitably lead to loss of visibility (Carter et al., 2015; Busse et al., 2017), and thus to potential risks for buying firms of not being able to detect 'sustainability misconduct' lurking in the complexity of the supply network (Meinlschmidt et al., 2016). These studies reveal undesired effects for buying companies resulting from complex supply networks, such as lower operational and environmental performance (Bozarth et al., 2009; Tachizawa and Wong, 2015), increasing transaction costs (Choi and Krause, 2006), disruptions (Bode and Wagner, 2015) and 
sustainability risks (Busse et al., 2017).

Some researchers have proposed that key factors for successful SCM is that buying firms re-conceptualize who is in the supply chain (Pagell and Wu, 2009) and reduce their supplier base (Choi and Krause, 2006). These approaches assume that even though there are some aspects of the complexity that are outside the managerial purview of the focal company, it can manage its first-tier suppliers (Choi and Krause, 2006). By only managing these suppliers, the buying firms c an contribute to mitigating complexity in the SCM and thereby reduce any potential misconduct (Vurro et al., 2009).

Looking at the supply netw ork derived from multiple sourcing strategies, the advantage of interconnections among suppliers, which $\mathrm{w}$ ould facilitate the spread of innovation across the supply network, could be counterbalanced by increasing complexity in the supply network structure. Multiple sourcing leads to inherently complex network structures because the buying companies have to rely on more than one supplier for the same component. In this scenario, the complexity of the structure can derive from an increasing supply base (vertical complexity), as w ell as, from increasing interconnections among suppliers (horizontal complexity) or even from both: vertical and horizontal complexity. In all these cases, we suggest that the increasing complexity of the supply network structure entails the risk that information might be located in a particular area of netw ork, limiting the flow of information and consequently the spread of innovation across the entire supply network. If the buying company increases its supply base but not interconnection among suppliers, the number of positionally embedded buyer-suppliers increase due to the creation of multiple unconnected subnetw orks (or 'ego-netw ork w eakness'), w hich according to recent research $\mathrm{w}$ ould mitigate any effects o $\mathrm{n}$ i nnovation ( Carnovale and Yeniyurt, 2015). Indeed, 'ego-network weakness' relies on the capacity of focal firms to a ct a s a b roker in diffusing in formation am ong the subnetworks. Increasing bridges can either facilitate or restrict the flow of information (Carnovale and Yeniyurt, 2015). Applied to our context, if the number of bridges increases, the advantages of interconnection betw een suppliers generated by multiple sourcing strategy might be neutralized by excessive coordination costs that the buyer has to bear.

On the other hand, in line with studies by Uzzi (1997) and Ahuja et al. (2009), if the buying company maintains the supply base and increases interconnection among suppliers, the number of positionally embedded buyer-suppliers increase due to the creation of redundant ties, which after a certain point might have marginal effects on collaboration behaviours and then on to performance. Paradoxically excessive embeddedness of companies can lead firms to became isolated from information that exists beyond their netw ork (Uzzi, 1997), introducing possible rigidities into cooperation and hindering the ability of firms to p ursue outstanding results (Ahuja et al., 2009).

Hence, we posit that increasing buyer-supplier positional embeddedness can on the one hand restrict the possibility of spreading innovation outside the pool of highly embedded partners and, on the other hand, access external information that can benefit cooperation. This effect is also present in the case of increasing environmental R\&D.

Hypothesis 3a. Buyer-supplier positional embeddedness (combined supply network centrality) amplifies the effects of environmental $R \& D$ cooperation on the production of low-carbon products up to a threshold, after which if the positional embeddedness increases, the moderation effect is reduced.

Hypothesis 3b. Buyer-supplier positional embeddedness (combined supply network centrality) amplifies the effects of environmental $R \& D$ cooperation on the production of low-carbon products up to a threshold, after which if the positional embeddedness and environmental $R \& D$ increase, the moderation effect is reduced.

\footnotetext{
${ }^{2}$ The supply network structure will assume a shape similar to a windmill, where there will be many suppliers with high positional embeddedness.
}

\section{Method}

\subsection{Data and sample}

We test our model using panel data on R\&D cooperation, supply structure and environmental performance in the automotive industry for the period 2001-2008. We focus on this timeframe because in 2009 carbon emission reductions from passenger cars became mandatory (EC 443/2009). ${ }^{3}$ During this time the industry experienced high regulatory uncertainty (Rothenberg and Ettlie, 2011) and huge barriers to incorporating carbon constraints into supply chain strategies (Lee, 2011), making environmental $\mathrm{R} \& \mathrm{D}$ cooperation particularly challenging. Therefore, we analyse the efforts of supply chain partners in reducing carbon emissions from products in a still unregulated context.

The panel dataset is drawn from different sources (see Table A1 in the appendix A). We rely on data from the Community Research and Development Information Service (CORDIS) to measure environmental R\&D cooperation. CORDIS is an official data source of the European Commission that collects information on projects in which organizations cooperate to carry out specific themes defined in the European Framework Programmes. IHS SupplierBusiness is used to understand the sourcing strategy of a buyer, and consequently the positional embeddedness (network centrality) of each organization in the supply chain structure. IHS SupplierBusiness provides detailed information about production relationships between buyers and suppliers in the automotive industry. It covers approximately $83 \%$ of the total car models produced in Europe, and is the most comprehensive database available in the market. Information concerning supplier parks is collected by Automotive News and financial information is based on Amadeus and Worldscope datasets. Finally, carbon emissions from vehicles are computed by using data from the Vehicle Certification Agency (VCA). This latter organization is a Vehicle Type Approval authority that provides vehicle certifications applying the European Union Directive 80/1268/EEC.

After merging these sources, a total of 205 dyadic relationships between automakers and their first-tier suppliers are retained, obtaining an unbalanced panel database of 1201 dyad-year observations. The automakers included in the study are BMW, Citroën, Fiat, Ford Europe, Mercedes, Opel-Vauxhall, Peugeot, Porsche, Renault, Volkswagen and Volvo. We consider 81 suppliers including Grupo Antolin, Autoliv, Bosch, Delphi, DENSO, Freudenberg, Johnson Controls, Magna International, Mondragon, Philips, TRW, Valeo, VARTA, and ZF among others.

\subsection{Measures}

\subsubsection{Supply chain structure}

Before computing the variables of the model, IHS SupplierBusiness data is used to build the supply chain structure per automaker in each year. We first identified all relationships between an automaker and its first-tier suppliers (all vertical ties) and all the relationships in the supply network (all horizontal ties among first-tier suppliers). The vertical ties were established due to the material flow existing between an automaker and a supplier, whereas horizontal ties were established when two or more suppliers pertained to the same material flow (e.g. Kim et al., 2011). The vertical ties were computed by counting the number of components delivered by suppliers to a specific buyer. The horizontal ties were computed by counting the number of shared components delivered by two or more suppliers to a same automaker. The number of components therefore captured the strength of ties between a buyer and a supplier and among suppliers (e.g. Granovetter, 1973).

\footnotetext{
${ }^{3}$ This time frame also ensures our results to be safe from manipulation emission tests concerning to the Volkswagen's scandal.
} 
In our sample, the analysis revealed that the supply chain structure changed over time. New suppliers came in and others left the supply chain due to: the launching of new vehicle models; a new generation of existing vehicle models or to the end of the production of particular vehicle models. Hence, we obtained an unbalanced panel dataset.

\subsubsection{Dependent variable}

The variable low-carbon product is the average of $\mathrm{CO}_{2}$ emissions of all vehicle models that are produced by a specific buyer-supplier dyad from 2001 to 2008. We first identified the $\mathrm{CO}_{2}$ emissions for all vehicle models produced by each dyad and year. The $\mathrm{CO}_{2}$ emissions for each vehicle model was estimated as the average of $\mathrm{CO}_{2}$ emissions of all vehicle versions of that model in each year, as listed in the VCA dataset. Since automakers offer different versions of the same vehicle model across time, this measure captures the full spectrum of $\mathrm{CO}_{2}$ emissions per year. Then, the average of $\mathrm{CO}_{2}$ emissions of all vehicle models produced by a dyad-year was computed as follows:

$\mathrm{CO}_{2}$ emissions dyad-year $=\frac{\sum_{i=1}^{N} \mathrm{CO}_{2} \text { Emissions }_{i}}{N}$

where "i" stands for the number of different versions of vehicle models and $\mathrm{N}$ the total number of models produced by the dyad. Low levels of this variable indicates that companies are producing low carbon products.

\subsubsection{Independent variables}

All independent variables refer to the period 2000-2007 (i.e. one year lagged). In line with other studies on alliance formation (Ahuja, 2000; Ahuja et al., 2009; Yeniyurt et al., 2009), the variable environmental $R \& D$ cooperation is measured as the cumulative R\&D linkages formed by an automaker and its suppliers in a given year. Looking at R\& D projects listed under the Fifth, Sixth and Seventh Framework Programme (FP5, FP6 and FP7) and collected in the CORDIS database, ${ }^{4}$ we identified all linkages between a buyer and its suppliers, excluding reverse-ordered pairs (see Ahuja et al., 2009). Hence, we retained all those projects where at least one automaker and a first-tier supplier cooperated. A total of 205 dyads were identified as R\&D cooperation. Within R\&D linkages, then, two distinct forms of collaboration were identified: environmental and non-environmental. R\&D linkages were coded as 'environmental cooperation' if they were related to FP5 "Energy, Environment and Sustainable Development", FP6 "Sustainable Development" or FP7 "Environment (including climate change)" projects. Otherwise, R\&D linkages were coded as non-environmental cooperation. Following previous studies, for each dyad-year observation, we then computed the intensity of environmental R\&D cooperation by accumulating the projects in which the automaker and the first-tier supplier cooperated until each year (Yeniyurt et al., 2009; Hottenrott and Lopes-Bento, 2016). To test for the expected non-linear effects of high levels of intensity, the square of environmental R\&D cooperation is also added into the models.

The variable positional embeddedness (combined centrality) is calculated using Bonacich's (1987) eigenvector centrality scores (Gulati and Gargiulo, 1999; Polidoro et al., 2011). Eigenvector centrality gives greater weight to a node that is connected to other highly connected nodes. In other words, a node connected to five high-scoring nodes will have higher eigenvector centrality than a node connected to five lowscoring nodes. This measure perfectly fits with our study because it takes into account that a supplier has greater scope for disseminating information when it is linked to a greater number of suppliers and when

\footnotetext{
${ }^{4}$ FP5, FP6 and FP7 set out the priorities for the European Union's research, technological development and demonstration (RTD) activities for the period 2000-2007 and are a reference point for understanding the strategic orientation of companies that wish to innovate in a particular field and, at the same time, cooperate with different organizations (Minin et al., 2010).
}

these suppliers are, furthermore, connected with many other suppliers. For each year, we computed the eigenvector measure of the network centrality of each buyer and supplier in the supply chain structure using $\mathrm{R}$ project software. The resulting scores were then normalized relative to the most central firm in that year. ${ }^{5} \mathrm{~A}$ high value of this measure indicates a high similarity in centrality of the organizations in the dyad. This means that the closer the dyadic score is to 1 , the more similar is the supplier's position in the network to the buyer's position. To test for the expected non-linear effects of high levels of complexity in the supply chain structure, the square of positional embeddedness is also included in the corresponding models.

\subsubsection{Control variables}

We also control for several variables that can affect the production of low-carbon products: supplier parks, product portfolio, supplier segment specialization, supplier base, buyer base, supplier size and buyer's size. The variable supplier parks was computed as the percentage of presence of a supplier in the automaker's supplier parks. We first identified the number of automakers' plants associated to a supplier park. Then, we counted the number of supplier parks where the supplier was present. The dyadic value was calculated as the ratio between the number of supplier parks, where the supplier was present, over the automaker's total suppliers parks. A high value for this variable indicates a high supplier's presence in the automaker's supplier parks. Product portfolio was estimated as the number of vehicle models shared by an automaker and a supplier over the automaker's total vehicle models. A high value for this variable indicates a high degree of participation in the automaker's total vehicle models portfolio. Supplier segment specialization was calculated as the difference between the average of the weight of the automaker's total vehicle models and average weight of vehicle models shared by an automaker and a supplier. A high value for this variable reflects the high level of specialization of the supplier in small vehicle models. Supplier base is the number of suppliers with which an automaker has procurement relationships (i.e. its supplier portfolio). A high value for this variable indicates that an automaker managed a large number of suppliers for procurement services. Buyer base is the number of automakers that were clients of a particular supplier. A high value for this variable indicates that a supplier was shared among several automakers, and that potential indirect effects from other supply chain relationships may occur. Lastly, the size of the automaker and of the supplier was calculated as the logarithm of the total asset.

All these control variables were computed for the period 2000-2007. Controls for the time effects through dummy variables for the years 2000-2007 were also included in the model, omitting the year 2000 dummy to avoid over-determination.

\section{Findings}

The descriptive statistics and the correlation matrix of the variables used in the analysis are showed in Table A2 and Table A3 of the Appendix A.

To select the best fitting model, we use the Lagrange multiplier test (Breusch and Pagan, 1980), finding that panel estimation is more appropriate than pooled OLS estimation. Under panel regression specification, Hausman (1978) test indicates that the estimated coefficients through fixed effects regression models are more consistent and efficient than those obtained through random effects regression modelization. Tables 1 to 5 display the models with the estimated effects of R\&D cooperation, the positional embeddedness, and the interplay between both on the production of low-carbon products. For these effects, we also test for model misspecification by applying Ramsey's (1969)

\footnotetext{
${ }^{5}$ Since we have a supply chain network, the buyer always has the maximum score.
} 
Table 1

Panel fixed-effects re gression an alysis: te sting li near an d qu adratic environmental R\&D cooperation.

\begin{tabular}{|c|c|c|c|}
\hline \multirow[t]{2}{*}{ Variables } & \multicolumn{3}{|c|}{$\begin{array}{l}\text { Low carbon products }\left(\mathrm{CO}_{2} \text { emissions from passenge }\right. \\
\text { cars) }\end{array}$} \\
\hline & Model 1I & $\begin{array}{l}\text { Model 1II } \\
\text { (H1a) }\end{array}$ & $\begin{array}{l}\text { Model 1III } \\
\text { (H1b) }\end{array}$ \\
\hline Env R\&D cooperation & & $\begin{array}{l}-2.492^{* * *} \\
(1.068)\end{array}$ & $\begin{array}{l}1.399 \\
(1.658)\end{array}$ \\
\hline $\begin{array}{l}\text { Env R\&D cooperation } \\
\text { squared }\end{array}$ & & & $\begin{array}{l}-1.869^{\text {ankt }} \\
(0.611)\end{array}$ \\
\hline Supplier parks & $\begin{array}{l}-0.016 \\
(0.015)\end{array}$ & $\begin{array}{l}-0.017 \\
(0.015)\end{array}$ & $\begin{array}{l}-0.020 \\
(0.015)\end{array}$ \\
\hline Product portfolio & $\begin{array}{l}-0.011 \\
(0.028)\end{array}$ & $\begin{array}{l}-0.016 \\
(0.028)\end{array}$ & $\begin{array}{l}-0.018 \\
(0.028)\end{array}$ \\
\hline $\begin{array}{r}\text { Supplier segment } \\
\text { specialization }\end{array}$ & $\begin{array}{l}-0.037^{*} \\
(0.005)\end{array}$ & $\begin{array}{l}-0.037^{* \ldots * k} \\
(0.005)\end{array}$ & $\begin{array}{l}-0.035 \\
(0.005)\end{array}$ \\
\hline Supplier base & $\begin{array}{l}0.137^{\text {theke }} \\
(0.023)\end{array}$ & $\begin{array}{l}0.136^{* x+k} \\
(0.023)\end{array}$ & $\begin{array}{l}0.139^{\text {*k+k }} \\
(0.023)\end{array}$ \\
\hline Buyer base & $\begin{array}{l}0.288^{* * k} \\
(0.137)\end{array}$ & $\begin{array}{l}0.237^{*} \\
(0.138)\end{array}$ & $\begin{array}{l}0.258 \\
(0.138)\end{array}$ \\
\hline Size (Automaker) & $\begin{array}{l}-7.496^{* * * k} \\
(1.746)\end{array}$ & $\begin{array}{l}-7.728^{* * 2 * 1} \\
(1.745)\end{array}$ & $\begin{array}{l}-7.869^{* * * * *} \\
(1.738)\end{array}$ \\
\hline Size (Supplier) & $\begin{array}{l}0.535 \\
(1.465)\end{array}$ & $\begin{array}{l}0.865 \\
(1.469)\end{array}$ & $\begin{array}{l}0.536 \\
(1.466)\end{array}$ \\
\hline F-value & $52.87^{\text {vikex }}$ & $50.13^{* * * *}$ & $48.13^{\text {tikek }}$ \\
\hline R-squared (within) & 0.4470 & 0.4501 & 0.4553 \\
\hline
\end{tabular}

Note: The sample size is 1201 dyad-year observations for 205 dyads (i.e. automaker and first-tier supplier). The standard errors are in parentheses. The dependent variable is the average of $\mathrm{CO}_{2}$ emissions levels from passenger cars produced by each dyad-year. The independent variables are environmental R\& D cooperation (linear effect) and its squared (curvilinear effect). Dummy variables for years are included in all the models, but they are not reported.

* Significance level: $\mathrm{p}<0.1$.

** Significance level: $\mathrm{p}<0.05$.

$* * *$ Significance level: $\mathrm{p}<0.01$.

Regression Specification Error Test (RESET) ${ }^{6}$ with two power orders as regressors (i.e. squared and cubed fitted values). Using the conventional threshold of 0.05 (see Lee et al., 1993), the null hypothesis of correct specification (i.e. Ho: the model has no omitted variable) is not rejected in all proposed models (see Table A4 in the Appendix A).

Table 1 exhibits the results of testing the hypotheses associated with the direct effects of environmental R\&D cooperation on product environmental performance. Model 1I shows the outcomes of the regression including only the control variables, and serves as a baseline model. Model 1II displays the linear effects of environmental R\&D cooperation on product performance (Hypothesis 1a) and Model 1III the presence of non-monotonic relationships (Hypothesis $1 \mathrm{~b}$ ). The variable environmental $R \& D$ cooperation is negative and significant ( $\mathrm{p}<0.05$ ), supporting the hypothesis that buyer-supplier environmental R\&D cooperation fosters the production of low-carbon vehicles. In other words, the vehicle models produced by a buyer and a supplier engaged in environmental R\&D cooperation emit on average less levels of carbon emissions over time. Therefore, the results support Hypothesis 1a. However, the weakness of the RESET test for this hypothesis (pvalue $=0.0704$ ) and the theoretical arguments about the presence of non-monotonic relationships lead us to treat this result with caution.

In contrast, the Hypothesis $1 \mathrm{~b}$ is partially supported. Environmental R\&D cooperation squared is significant $(\mathrm{p}<0.01)$ but still negative, indicating that the relationship between environmental R\&D cooperation and performance is not linear, but that the production of lowcarbon product does not present decreasing marginal effects when

\footnotetext{
${ }^{6}$ This test is typically done in OLS models, but modified versions can be done in fixed effects models.
}

Table 2

Panel fixed-effects regression analysis: testing interaction between positional embeddedness and environmental R\&D cooperation.

\begin{tabular}{|c|c|c|}
\hline \multirow[t]{2}{*}{ Variables } & \multicolumn{2}{|c|}{$\begin{array}{l}\text { Low carbon products }\left(\mathrm{CO}_{2} \text { emissions from }\right. \\
\text { passenger cars) }\end{array}$} \\
\hline & Model 2I & Model 2II (H2a) \\
\hline Env R\&D cooperation & $\begin{array}{l}-2.387^{* * k} \\
(1.063)\end{array}$ & $\begin{array}{l}-3.313^{* * *} \\
(1.121)\end{array}$ \\
\hline Positional embeddedness & $\begin{array}{l}-0.124^{\text {iktike }} \\
(0.039)\end{array}$ & $\begin{array}{l}-0.114^{\text {t.t.kx }} \\
(0.039)\end{array}$ \\
\hline $\begin{array}{l}\text { Env R\&D coop. } x \text { P. } \\
\text { embeddedness }\end{array}$ & & $\begin{array}{l}-0.056^{* * k} \\
(0.022)\end{array}$ \\
\hline Supplier parks & $\begin{array}{l}-0.016 \\
(0.015)\end{array}$ & $\begin{array}{l}-0.018 \\
(0.015)\end{array}$ \\
\hline Product portfolio & $\begin{array}{l}-0.042 \\
(0.030)\end{array}$ & $\begin{array}{l}-0.045 \\
(0.029)\end{array}$ \\
\hline Supplier segment specialization & $\begin{array}{l}-0.037^{* k+k} \\
(0.005)\end{array}$ & $\begin{array}{l}-0.034^{\text {k.k.k. }} \\
(0.005)\end{array}$ \\
\hline Supplier base & $\begin{array}{l}0.129^{* * \times k} \\
(0.023)\end{array}$ & $\begin{array}{l}0.128^{\text {tentiot }} \\
(0.023)\end{array}$ \\
\hline Buyer base & $\begin{array}{l}0.243^{*} \\
(0.138)\end{array}$ & $\begin{array}{l}0.244^{*} \\
(0.139)\end{array}$ \\
\hline Size (Automaker) & $\begin{array}{l}-8.308^{\text {it*k }} \\
(1.746)\end{array}$ & $\begin{array}{l}-8.397^{\text {k*k* }} \\
(1.742)\end{array}$ \\
\hline Size (Supplier) & $\begin{array}{l}1.292 \\
(1.468)\end{array}$ & $\begin{array}{l}1.224 \\
(1.464)\end{array}$ \\
\hline F-value & $48.23^{* * * *}$ & $46.16^{\text {t*k*kx }}$ \\
\hline R-squared (within) & 0.4558 & 0.4593 \\
\hline
\end{tabular}

Note: The sample size is 1201 dyad-year observations for 205 dyads (i.e. automaker and first-tier supplier). The standard errors are in parentheses. The dependent variable is the average of $\mathrm{CO}_{2}$ emissions levels from passenger cars produced by each dyad-year. The independent variables are environmental $\mathrm{R} \&$ $\mathrm{D}$ cooperation, positional embeddedness and the interaction term between both. Dummy variables for years are included in all the models, but they are not reported.

* Significance level: $\mathrm{p}<0.1$.

$* *$ Significance level: $\mathrm{p}<0.05$

$* * *$ Significance level: $\mathrm{p}<0.01$.

environmental R\&D cooperation increases. The absence of an inflexion point in fact means that product performance continues to benefit from increasing R\&D cooperation.

Table 2 shows the result of adding the direct effects of positional embeddedness and the moderation effects of positional embeddedness on the relationship between environmental R\&D cooperation and product environmental performance (Hypothesis 2a). The variable positional embeddedness is negative and significant $(\mathrm{p}<0.01)$, indicating that when buyer-supplier dyads occupy a central position in the supply network structure, on average they produce low-carbon products. The interaction term is also negative and significant $(\mathrm{p}<0.05)$. This implies that when these dyads cooperate for environmental innovation, thanks to their central position, they are also able to amplify the effects of their cooperation on performance. Therefore, Hypothesis 2a is supported.

Table 3 shows the results of testing the moderation effects of positional embeddedness for environmental R\&D cooperation (Hypothesis $2 \mathrm{~b})$. The interaction term squared is positive, but not significant. This implies that for increasing R\&D cooperation, non-significant effects are produced by the positional embeddedness of partners on product performance. In other words, the marginal effects produced by excessive $\mathrm{R}$ \&D cooperation on environmental performance are neither neutralized, nor counterbalanced, by positional embeddedness. Hence, the Hypothesis $2 \mathrm{~b}$ is not supported.

Table 4 and Table 5 show the results of testing the moderation effects of increasing positional embeddedness (i.e. complexity) on the relationship between environmental R\&D cooperation and product performance (Hypothesis 3a) and the non-monotonic effects of both positional embeddedness and R\&D cooperation (Hypothesis 3b). In 
Table 3

Panel fixed-effects re gression an alysis: te sting in teraction be tw eenpositional embeddedness and curvilinear environmental R\&D cooperation.

\begin{tabular}{|c|c|c|c|}
\hline \multirow[t]{2}{*}{ Variables } & \multicolumn{3}{|c|}{$\begin{array}{l}\text { Low carbon products }\left(\mathrm{CO}_{2} \text { emissions from passenger }\right. \\
\text { cars) }\end{array}$} \\
\hline & Model 3I & Model 3II & $\begin{array}{l}\text { Model 3III } \\
\text { (H2b) }\end{array}$ \\
\hline Env R\&D cooperation & $\begin{array}{l}1.184 \\
(1.653)\end{array}$ & $\begin{array}{l}-0.213 \\
(1.830)\end{array}$ & $\begin{array}{l}-0.416 \\
(2.224)\end{array}$ \\
\hline $\begin{array}{l}\text { Env R\&D cooperation } \\
\text { squared }\end{array}$ & $\begin{array}{l}-1.719^{\text {inkx }} \\
(0.610)\end{array}$ & $\begin{array}{l}-1.372^{\text {*k }} \\
(0.641)\end{array}$ & $\begin{array}{l}-1.314^{*} \\
(0.734)\end{array}$ \\
\hline Positional embeddedness & $\begin{array}{l}-0.115^{* \ldots * *} \\
(0.039)\end{array}$ & $\begin{array}{l}-0.109^{3+2 \times k} \\
(0.039)\end{array}$ & $\begin{array}{l}-0.112^{* k * k} \\
(0.043)\end{array}$ \\
\hline $\begin{array}{l}\text { Env R\&D coop. x P. } \\
\text { embeddedness }\end{array}$ & & $\begin{array}{l}-0.041 \\
(0.018)\end{array}$ & $\begin{array}{l}-0.048^{*} \\
(0.026)\end{array}$ \\
\hline $\begin{array}{l}\text { Env R\&D coop. squared x P. } \\
\text { embeddedness }\end{array}$ & & & $\begin{array}{l}0.002 \\
(0.015)\end{array}$ \\
\hline Supplier parks & $\begin{array}{l}-0.018 \\
(0.015)\end{array}$ & $\begin{array}{l}-0.019 \\
(0.015)\end{array}$ & $\begin{array}{l}-0.019 \\
(0.015)\end{array}$ \\
\hline Product portfolio & $\begin{array}{l}-0.042 \\
(0.029)\end{array}$ & $\begin{array}{l}-0.044 \\
(0.029)\end{array}$ & $\begin{array}{l}-0.045 \\
(0.030)\end{array}$ \\
\hline $\begin{array}{l}\text { Supplier segment } \\
\text { specialization }\end{array}$ & $\begin{array}{l}-0.035^{*} \\
(0.005)\end{array}$ & $\begin{array}{l}-0.033^{\text {nthet }} \\
(0.005)\end{array}$ & $\begin{array}{l}-0.034^{\text {*k⿲丿. }} \\
(0.005)\end{array}$ \\
\hline Supplier base & 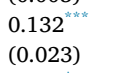 & $\begin{array}{l}0.130^{\text {k*k*n }} \\
(0.023)\end{array}$ & $\begin{array}{l}0.130^{* * * * k} \\
(0.023)\end{array}$ \\
\hline Buyer base & $\begin{array}{l}0.224^{3} \\
(0.136)\end{array}$ & $\begin{array}{l}0.250^{* k} \\
(0.138)\end{array}$ & $\begin{array}{l}0.250 \\
(0.139)\end{array}$ \\
\hline Size (Automaker) & $\begin{array}{l}-8.395^{\text {(1. }} \\
(1.740)\end{array}$ & $\begin{array}{l}-8.443^{2} \\
(1.739)\end{array}$ & $\begin{array}{l}-8.431^{\text {k.k. }} \\
(1.741)\end{array}$ \\
\hline Size (Supplier) & $\begin{array}{l}0.958 \\
(1.468)\end{array}$ & $\begin{array}{l}0.976 \\
(1.466)\end{array}$ & $\begin{array}{l}0.957 \\
(1.471)\end{array}$ \\
\hline F-value & $46.31^{k \cdots * k}$ & $44.13^{k * * *}$ & $41.89^{* * * x}$ \\
\hline R-squared (within) & 0.4601 & 0.4619 & 0.4620 \\
\hline
\end{tabular}

Note: The sample size is 1201 dyad-year observations for 205 dyads (i.e. automaker and first-tier supplier). The standard errors are in parentheses. The dependent variable is the average of $\mathrm{CO}_{2}$ emissions levels from passenger cars produced by each dyad-year. The independent variables are environmental $\mathrm{R} \&$ D cooperation and its squared (curvilinear effect), positional embeddedness and the interaction terms between them. Dummy variables for years are included in all the models, but they are not reported.

* Significance level: $\mathrm{p}<0.1$.

** Significance level: $\mathrm{p}<0.05$.

$* * *$ Significance level: $\mathrm{p}<0.01$.

both tables, the variable positional embeddedness squared (i.e. complexity) is positive and significant ( $\mathrm{p}<0.01)$. This implies that high complexity supply chain structure works against the production of lowcarbon vehicles. However, this opposite effect is not transferred to the moderated interplay. In other words, none of the interaction terms squared are significant. This means that the excessive positional embeddedness of partners engaged in R\&D cooperation has no significant impact on environmental performance. Consequently, our findings do not support the idea that after a threshold, complexity in the supply chain structure plays a counterbalancing role on the relationship between environmental R\&D cooperation and product performance (Table 4). This finding also holds under the presence of excessive R\&D cooperation (Table 5). Therefore, Hypotheses $3 \mathrm{a}$ and $3 \mathrm{~b}$ are not supported.

With regard to the control variables, supplier segment specialization is negative and significant $(\mathrm{p}<0.01)$. This means that suppliers that specialize in small vehicle models are associated with lower $\mathrm{CO}_{2}$ emissions levels. Supplier base and buyer base are both positive and significant ( $\mathrm{p}<0.01$ and 0.10 respectively). Having a large number of suppliers leads to the production of vehicles with higher carbon emissions, and similarly, when a supplier has a large number of buyers, the vehicles in which it is involved tend to emit, on average, higher carbon
Table 4

Panel fixed-effects regression analysis: testing interaction between curvilinear positional embeddedness and environmental R\&D cooperation.

\begin{tabular}{|c|c|c|c|}
\hline \multirow[t]{2}{*}{ Variables } & \multicolumn{3}{|c|}{$\begin{array}{l}\text { Low carbon products }\left(\mathrm{CO}_{2} \text { emissions from passenger }\right. \\
\text { cars) }\end{array}$} \\
\hline & Model 4I & Model 4II & $\begin{array}{l}\text { Model 4III } \\
\text { (H3a) }\end{array}$ \\
\hline Env R\&D cooperation & $\begin{array}{l}-3.070^{* \ldots * k} \\
(1.057)\end{array}$ & $\begin{array}{l}-4.475^{\text {w*ktk }} \\
(1.120)\end{array}$ & $\begin{array}{l}-5.599^{\text {a.k. }} \\
(1.975)\end{array}$ \\
\hline Positional embeddedness & $\begin{array}{l}-0.029 \\
(0.042)\end{array}$ & $\begin{array}{l}-0.001 \\
(0.043)\end{array}$ & $\begin{array}{l}-0.009 \\
(0.044)\end{array}$ \\
\hline $\begin{array}{l}\text { Positional embeddedness } \\
\text { squared }\end{array}$ & $0.006^{\text {knk }}$ & $0.006^{* \ldots \times n}$ & $0.006^{* \ldots \ldots k}$ \\
\hline $\begin{array}{l}\text { Env R\&D coop. } x \text { P. } \\
\text { embeddedness }\end{array}$ & & $\begin{array}{l}-0.080^{*} \\
(0.022)\end{array}$ & $\begin{array}{l}-0.078^{*} \\
(0.022)\end{array}$ \\
\hline $\begin{array}{l}\text { Env R\&D coop. } \mathrm{x} \text { P. } \\
\text { embeddedness squared }\end{array}$ & & & $\begin{array}{l}0.001 \\
(0.001)\end{array}$ \\
\hline Supplier park & $\begin{array}{l}-0.014 \\
(0.015)\end{array}$ & $\begin{array}{l}-0.017 \\
(0.015)\end{array}$ & $\begin{array}{l}-0.016 \\
(0.015)\end{array}$ \\
\hline Product portfolio & $\begin{array}{l}-0.043 \\
(0.029)\end{array}$ & $\begin{array}{l}-0.046 \\
(0.029)\end{array}$ & $\begin{array}{l}-0.047 \\
(0.029)\end{array}$ \\
\hline $\begin{array}{r}\text { Supplier segment } \\
\text { specialization }\end{array}$ & $\begin{array}{l}-0.038^{* 2 \ldots} \\
(0.005)\end{array}$ & $\begin{array}{l}-0.034^{* * *} \\
(0.005)\end{array}$ & $\begin{array}{l}-0.035^{* * *} \\
(0.005)\end{array}$ \\
\hline Supplier base & 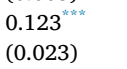 & $\begin{array}{l}0.120^{* \ldots * k} \\
(0.023)\end{array}$ & $\begin{array}{l}0.120 \\
(0.023)\end{array}$ \\
\hline Buyer base & $\begin{array}{l}0.349^{* * *} \\
(0.139)\end{array}$ & $\begin{array}{l}0.427^{\text {k**** }} \\
(0.140)\end{array}$ & $\begin{array}{l}0.421^{\text {. }} \\
(0.140)\end{array}$ \\
\hline Size (Automaker) & $\begin{array}{l}-9.103 \\
(1.730)\end{array}$ & $\begin{array}{l}-9.333^{\text {* }} \\
(1.720)\end{array}$ & $\begin{array}{l}-9.227 \\
(1.728)\end{array}$ \\
\hline Size (Supplier) & $\begin{array}{l}1.413 \\
(1.449)\end{array}$ & $\begin{array}{l}1.332 \\
(1.440)\end{array}$ & $\begin{array}{l}1.324 \\
(1.440)\end{array}$ \\
\hline F-value & $48.30^{* * * *}$ & $47.01^{* \ldots * k}$ & $44.66^{* * * k}$ \\
\hline R-squared (within) & 0.4706 & 0.4776 & 0.4778 \\
\hline
\end{tabular}

Note: The sample size is 1201 dyad-year observations for 205 dyads (i.e. automaker and first-tier supplier). The standard errors are in parentheses. The dependent variable is the average of $\mathrm{CO}_{2}$ emissions levels from passenger cars produced by each dyad-year. The independent variables are environmental $\mathrm{R} \&$ D cooperation, positional embeddedness and its squared (curvilinear effect), and the interaction terms between them. Dummy variables for years are included in all the models, but they are not reported.

$* *$ Significance level: $\mathrm{p}<0.05$.

$* * *$ Significance level: $\mathrm{p}<0.01$.

emissions over time. Finally, while the size of the automaker matters for environmental performance, the size of the supplier does not seem to be linked with the production of low-carbon vehicles.

\section{Discussion and implications}

\subsection{Results discussion}

The literature has largely stressed the positive impact of R\&D cooperation on performance. This study, however, casts doubts on the effectiveness of environmental R\&D cooperation if it is assessed alone, suggesting that a comprehensive understanding of the success of supply chain environmental R\&D cooperation relies on how partners are positionally embedded in the supply network structure. Specifically, in a period of technology transition, environmental R\&D cooperation requires strong collaboration from partners, which makes embeddedness critical in the supply network. Given the complexity that sustainability introduces in the supply chain, effective environmental R\&D cooperation depends highly on the willingness of partners to restructure their production processes and to integrate new competence and knowledge derived from cooperation. Through assessing the role of the positional embeddedness of partners in the supply chain network, this study extends the knowledge about the dynamics that lead R\&D cooperation to 
Table 5

Panel fixed-effects regression analysis: testing interaction between curvilinear positional embeddedness and environmental R\&D cooperation.

\begin{tabular}{|c|c|c|c|c|}
\hline \multirow[t]{2}{*}{ Variables } & \multicolumn{4}{|c|}{ Low carbon products $\left(\mathrm{CO}_{2}\right.$ emissions from passenger cars) } \\
\hline & Model 5I & Model 5II & Model 5III & Model 5IV (H3b) \\
\hline Env R\&D cooperation & $\begin{array}{l}-0.680 \\
(1.633)\end{array}$ & $\begin{array}{l}-1.607 \\
(1.816)\end{array}$ & $\begin{array}{l}-2.089 \\
(2.705)\end{array}$ & $\begin{array}{l}-1.925 \\
(3.087)\end{array}$ \\
\hline Env R\&D cooperation squared & $\begin{array}{l}-1.811^{\text {k*** }} \\
(0.602)\end{array}$ & $\begin{array}{l}-1.264^{* * x} \\
(0.630)\end{array}$ & $\begin{array}{l}-1.228^{*} \\
(0.648)\end{array}$ & $\begin{array}{l}-1.331^{*} \\
(0.732)\end{array}$ \\
\hline Positional embeddedness & $\begin{array}{l}-0.018 \\
(0.042)\end{array}$ & $\begin{array}{l}0.001 \\
(0.043)\end{array}$ & $\begin{array}{l}-0.001 \\
(0.044)\end{array}$ & $\begin{array}{l}-0.001 \\
(0.044)\end{array}$ \\
\hline Positional embeddedness squared & $\begin{array}{l}0.006^{\text {and }} \\
(0.001)\end{array}$ & $\begin{array}{l}0.006^{\text {intinkt }} \\
(0.001)\end{array}$ & $\begin{array}{l}0.006 \\
(0.001)\end{array}$ & $\begin{array}{l}0.006^{2} \\
(0.001)\end{array}$ \\
\hline Env R\&D coop. x P. embeddedness & & $\begin{array}{l}-0.065 \\
(0.023)\end{array}$ & $\begin{array}{l}-0.065^{\text {ta }} \\
(0.023)\end{array}$ & $\begin{array}{l}-0.067^{2} \\
(0.027)\end{array}$ \\
\hline Env R\&D coop. x P. embeddedness squared & & & $\begin{array}{l}0.001 \\
(0.001)\end{array}$ & $\begin{array}{l}0.001 \\
(0.002)\end{array}$ \\
\hline $\begin{array}{l}\text { Env R\&D coop. squared x P. embeddedness } \\
\text { Squared }\end{array}$ & & & & $\begin{array}{l}0.000 \\
(0.001)\end{array}$ \\
\hline Supplier parks & $\begin{array}{l}-0.016 \\
(0.015)\end{array}$ & $\begin{array}{l}-0.018 \\
(0.015)\end{array}$ & $\begin{array}{l}-0.018 \\
(0.015)\end{array}$ & $\begin{array}{l}-0.018 \\
(0.015)\end{array}$ \\
\hline Product portfolio & $\begin{array}{l}-0.043 \\
(0.029)\end{array}$ & $\begin{array}{l}-0.046 \\
(0.029)\end{array}$ & $\begin{array}{l}-0.046 \\
(0.029)\end{array}$ & $\begin{array}{l}-0.046 \\
(0.029)\end{array}$ \\
\hline Supplier segment specialization & $\begin{array}{l}-0.036^{* \ldots *} \\
(0.005)\end{array}$ & $\begin{array}{l}-0.034^{\text {n.k.k }} \\
(0.005)\end{array}$ & $\begin{array}{l}-0.034^{\text {th*k }} \\
(0.005)\end{array}$ & $\begin{array}{l}-0.034^{\text {***k*k }} \\
(0.005)\end{array}$ \\
\hline Supplier base & $\begin{array}{l}0.126^{\text {knkxk }} \\
(0.023)\end{array}$ & $\begin{array}{l}0.123^{\text {k.knk }} \\
(0.023)\end{array}$ & $\begin{array}{l}0.122^{\text {nkxk }} \\
(0.023)\end{array}$ & $\begin{array}{l}0.123^{\text {*k*kx }} \\
(0.023)\end{array}$ \\
\hline Buyer base & $\begin{array}{l}0.374^{\text {wheth }} \\
(0.139)\end{array}$ & $\begin{array}{l}0.430 \\
(0.140)\end{array}$ & $\begin{array}{l}0.428 \\
(0.140)\end{array}$ & $\begin{array}{l}0.429^{3} \\
(0.140)\end{array}$ \\
\hline Size (Automaker) & $\begin{array}{l}-9.208^{* \ldots *} \\
(1.723)\end{array}$ & $\begin{array}{l}-9.365^{\text {thele }} \\
(1.718)\end{array}$ & $\begin{array}{l}-9.326^{\text {*ndx }} \\
(1.726)\end{array}$ & $\begin{array}{l}-9.333^{\text {thentith }} \\
(1.728)\end{array}$ \\
\hline Size (Supplier) & $\begin{array}{l}1.063 \\
(1.447)\end{array}$ & $\begin{array}{l}1.102 \\
(1.442)\end{array}$ & $\begin{array}{l}1.106 \\
(1.443)\end{array}$ & $\begin{array}{l}1.099 \\
(1.445)\end{array}$ \\
\hline F-value & $46.61^{* n+k}$ & $45.00^{k+k x+k}$ & $42.82^{* * *}$ & $40.83^{k+k * x}$ \\
\hline R-squared (within) & 0.4755 & 0.4797 & 0.4798 & 0.4798 \\
\hline
\end{tabular}

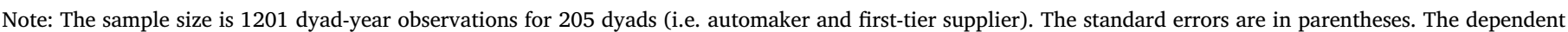

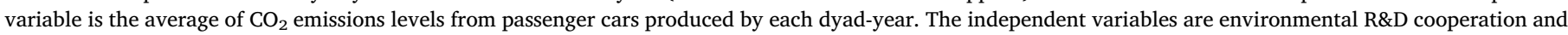

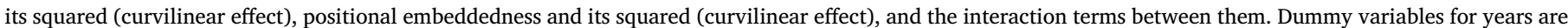
included in all the models, but they are not reported.

* Significance level: $\mathrm{p}<0.1$.

** Significance level: $\mathrm{p}<0.05$.

$* * *$ Significance level: $\mathrm{p}<0.01$.

successful outcomes.

Our results show that environmental R\&D cooperation between a buyer and its suppliers contributes to reducing carbon emissions from vehicles. This first outcome is consistent with previous research findings. Buyers and suppliers who cooperate on R\&D projects foster innovations that contribute to enhanced environmental performance (Klassen and Vachon, 2003; Vachon and Klassen, 2007; De Marchi, 2012). In line with the relational view, in R\&D cooperation, partners share competence, expertise and manufacturing knowledge, which can be especially crucial to the development of new technology (Dankbaar, 2007). R\&D cooperation between buyers and suppliers in fact offers the opportunity to exploit the suppliers' manufacturing expertise in the early stages of technology development. Suppliers know the characteristics of their materials and the machinery and equipment used to work with these materials, as well as different methods to connect parts together. Thus, they are able to anticipate if production is going to be easy or difficult, leading to effective innovation processes (Dankbaar, 2007). In this sense, R\&D cooperation between buyers and their suppliers can significantly contribute to improving the environmental sustainability of products over time.

Increasing intensity in environmental R\&D cooperation, however, does not have linear effects on the production of low-carbon product in a period of technological transition. Although it does not have counterbalanced effects on performance, if partners excessively increase the number of projects they work on, they might not have sufficient time to assimilate and implement new knowledge, consequently exploiting mostly incremental environmental innovation, which would derive in reduced marginal effects on product performance. Therefore, in the short term, increasing the number of cooperative relationships might not contribute to further improvements in product environmental performance for reasons linked to limited absorptive capacity and to technological boundaries of incremental innovation. Furthermore, in contrast to our predictions, the absence of a concave relationship between excessive environmental R\&D cooperation and the production of low-carbon products can be due to the regulatory uncertainty that characterizes the period under analysis. Studies show that regulatory uncertainty does not necessarily have significant effects on reducing investments in abatement measures (Hoffmann et al., 2009; De Stefano et al., 2016; Rodriguez Lopez et al., 2017). Rather, regulatory uncertainty can contribute to maintaining a certain level of cooperation for environmental innovation in order to mitigate future institutional actions and competition. Increasing environmental $R \& D$ cooperation, therefore, could provide the knowledge needed to maintain the progress achieved over time in terms of carbon emission reduction.

Findings also suggest that the positional embeddedness of partners triggered by multiple sourcing strategy matters for improving product environmental performance. The positional embeddedness of a buyer and a supplier is positively associated with the production of lowcarbon products. In line with the relational view, companies that occupy a central position in a network have the opportunity to collect and exploit valuable information and resources and obtain, as a consequence, increasing relational rents from cooperation. Consistently, when positional embeddedness is analysed together with participation in environmental R\&D projects, it can be seen that the effects of 
cooperation are amplified. $\mathrm{P}$ artners e ngaged i n e nvironmental R\&D cooperation that benefit from positional embeddedness in the network structure, have not only the advantage of accessing valuable resources and know ledge from the netw ork that facilities the cooperation, but also the pow er to encourage other suppliers to adopt innovative practices to avoid being excluded from the netw ork. This result is in line with studies that show that despite its costs, multiple sourcing is an optimal strategy in risky environments (Costantino and Pellegrino, 2010). In a context where the priority is to reduce carbon emissions from a product, the implementation of multiple sourcing is a tool in the buyer's hand that can alter the positional embeddedness of suppliers, putting them under greater competitive and cooperative pressures, with the benefit of a mplifying the e ffects of R\& $\mathrm{D}$ co operation on product performance. However, the results also show that an increasing number of R\&D projects carried out $w$ ith positionally embedded suppliers do not seem to amplify the effects of $\mathrm{R} \& \mathrm{D} \mathrm{c}$ ooperation o $\mathrm{n}$ p roduct environmental performance. When companies do not know $\mathrm{w}$ hat the dominant market standards might be, the joint effects of excessive R\&D cooperation and embeddedness may lead to possible limitations in experimenting $w$ ith new and different t echnologies that $m$ ight b e especially necessary in a period of technological transition, as in our context. Also, if buyers increase their cooperation $\mathrm{w}$ ith embedded suppliers, it is possible that they would reach a point in which potential further cooperation would not lead to further improvements because of redundancies in the information and limits in the technological competence of these partners. Thus, nothing additional $\mathrm{w}$ ould be transmitted in the supply netw ork with the consequence that marginal indirect effects o $\mathrm{n}$ e nvironmental $\mathrm{p}$ erformance $\mathrm{w}$ ould $\mathrm{n}$ ol onger be present.

Interestingly, increasing levels of embeddedness (i.e. complexity) are associated with the production of pollutant products. In agreement with Ahuja et al. (2009), we suggest that the same mechanisms that generate high positional embeddedness can also act as resistors to the introduction of environmental innovation, w hich in turn can reduce opportunities to produce low -carbon products. How ever, $w$ ith environmental R\&D cooperation, high positional embeddedness is not able to counterbalance the beneficial e ffects of $R \& D$ co operation on performance.

It is interesting to read the above results together with the positive effect that a r educed s upply $\mathrm{b}$ ase $\mathrm{c}$ an $\mathrm{h}$ ave o $\mathrm{n}$ e nvironmental performance (i.e., contributing to the reduction in carbon emissions from vehicles). This means that buyers need to manage their portfolio in such $\mathrm{a} \mathrm{w}$ ay that they have more than one supplier delivering the same component; while ensuring that their overall number of suppliers is not too high. This result is coherent $\mathrm{w}$ ith the idea of having selective portfolio strategies to obtain optimum supplier relationships (Wagner and Johnson, 2004), to enhance new product development (Goffin et al., 2006), and to achieve objectives of service degree and cost savings (Morrison et al., 2004; Pfohl and Gareis, 2005). Indeed, as suggested by Choi and Krause (2006), the management of the supply base is a complex issue because it involves not only the number of suppliers in the supply base, but also how they interact. These authors emphasize that although narrow supply base may lead to increased supplier responsiveness and efficiency, sharp re ductions may increase supply risk and reduce the willingness of suppliers to innovate $w$ ith the result of reducing the buying company's overall competitiveness (Choi and Krause, 2006). These arguments are coherent $w$ ith our results, which suggest balancing the need to have more than one supplier to provide the same component, in order to promote interactions among suppliers, while but containing the number of suppliers in the supply chain to reduce complexity and costs.

\subsection{Theoretical contributions}

According to Choi and Wu (2009) "dyadic relationships should be fully addressed only in a broader relationship context that includes relationships with other suppliers". In line with this argument, we offer a study in which the main objective is to understand how dyadic relationships involved in environmental R\&D cooperation work while their relationships in the supply network structure are also considered. In this context, our contribution to the SCM literature is twofold. By extending the relational view (Dyer and Singh, 1998), we analyse whether the interaction between dyads involved in environmental R\&D cooperation and their positional embeddedness amplify the effects of $\mathrm{R}$ $\& \mathrm{D}$ cooperation that lead to the production of low-carbon products. The positional embeddedness of partners can contribute to the effectiveness of R\&D cooperation by facilitating collaborative behaviours in the supply chain and the spreading of innovation to the rest of the supply network. Possible drawbacks of R\&D cooperation are explored by combining perspectives from the alliance and supply chain literature.

The second contribution of this work is that it offers a more comprehensive application of the relational view. This theoretical perspective discusses different types of collaborations and their effects on performance. It also identifies the types of mechanisms that increase the effects of collaboration on performance. Integrating arguments from network theory and specifically of embeddedness, this paper captures this standpoint in a more extensive way with respect to previous studies, which focus on fewer relationship characteristics, or do not offer interaction analyses. Furthermore, this paper extends the triadic approach by assessing the effects that supplier relationships and their interactions can have upon one another. There are still only a limited number of studies that take an integrated view of connections and interdependencies among suppliers in a network (Roseira et al., 2010).

\subsection{Managerial implications}

This study provides a number of practical insights for managers in the automotive industry. It suggests that managers of focal companies have to map and strategically manage their "visible" network, i.e. the relationships with their first-tier suppliers and the relationships that their first-tier suppliers have with other first-tier suppliers. Managers do not need to assess trust or commitment of suppliers when they engage in $R \& D$ cooperation. Managers who implement strategies such as multiple sourcing can design supply network structures that enable them to generate commitment from suppliers thanks to the network dynamics that these strategies produce.

In this context, we suggest that multiple sourcing strategy is a tool in the buying company's hands to promote relational equity in environmental R\&D cooperation. Relational equity is "the wealth-creating potential that resides in the firm's relationships with its stakeholder" (Sawhney and Zabin, 2002, p. 313). Following Sawhney and Zabin's line of thought, we recommend that managers consider the idea that effective management of relational equity relies on thinking about their suppliers not in isolation but embedded in the network structure. Managers have to consider that suppliers' relationships work as a systemic whole to form the value network. Thus, they need to carefully analyse the supply network to improve R\&D cooperation results.

This study also highlights the fact that focal companies do not need to cooperate with many suppliers to improve the environmental performance of products but just with those suppliers who are positionally embedded in the network structure. Through these suppliers the focal companies have the possibility to extend environmental innovations and associated best practices across the supply network. Managers therefore also have to manage the supply network and continually adapt it to improve relational equity through the diffusion of innovation across the supply chain. Notwithstanding this, in order to enhance the environmental performance of a product, managers must test varied supply network structures because increasing network complexity might neutralize the beneficial effects of R\&D cooperation on performance. In these terms, this study provides a practical tool for their decision-making process.

Finally, our findings also indicate that increasing cooperation with 
highly embedded suppliers might not always be good for exploring new technologies. This strategy can provide a good starting point, but it can also hugely limit the possibility of exploring new technologies to enhance product environmental performance in technological transition periods. Managers have therefore to assess their levels of cooperation, even $w$ ith firms from o utside the a utomotive industry. R ecent studies show that new market entrants can strongly contribute to the development of environmental innovation (Birkinshaw et al., 2007; Golembiewski et al., 2015; Nair et al., 2016). Managers could use environmental R\&D cooperation to improve the dialogue with other stakeholders such as government institutions and NGOs. Private-public cooperation in environmental innovation can help to design feasible carbon emission standards, since the current ones do not seem to work in the automotive industry (Puko et al., 2018).

\subsection{Concluding remarks, limitations and opportunities for future research}

Although this study has offered a novel perspective that has combined insights from qualitative studies, conceptual approaches and other theories, there is room for improvement. First, the timeframe is limited to the period 2001-2008 when companies w ere not subject to $\mathrm{CO}_{2}$ emission regulations. Future studies could verify the effectiveness of environmental $R \& D$ cooperation and its interactions on performance under the new regulated context. Second, the type of environmental technology that R\&D cooperation addresses (i.e. radical or incremental) is not identified. Further studies should explore how suppliers collaborate and contribute to the development of different types of technologies to improve the sustainability of product environmental performance over time. Third, complex components are not distinguished from simple components, nor are different weights attributed to particular components. Some components probably have a greater impact on vehicle carbon emission than others.

Finally, researchers have shown that the positive benefits of multiple sourcing in the production stage can be amplified by implementing a strategy of split sourcing instead of parallel sourcing. This strategy entails involving two or more suppliers that share component sourcing in the production of the same model. It has been shown that split sourcing strategies increase production efficiency more than parallel sourcing (Aláez-Aller and Longás-García, 2010). This study does not control this aspect. Hence, further research should explore the impact of different multiple sourcing strategies on improving the sustainability of product performance.

\section{Acknowledgements}

This research was supported by the Spanish Ministry of Economy and Competitiveness (Grant \# ECO2016-75961-R). Part of this work was also developed thanks to a Two-year Postdoctoral Mobility Program (Grant \# A4U) carried out by the first author at Pompeu Fabra University, Department of Economics and Business, Barcelona (Spain).

\section{Appendix A}

See Tables A1-A4

Table A1

Variable description.

\begin{tabular}{|c|c|c|}
\hline Variable & Description & Database \\
\hline Low-carbon vehicle & $\begin{array}{l}\text { Average } \mathrm{CO} \text { emissions [levels of } \mathrm{g} / \mathrm{km} \text { ] from all vehicle models in which a buyer-supplier dyad is } \\
\text { involved. }\end{array}$ & VCA \\
\hline Environmental R\&D cooperation & Cumulative number of R\&D projects wherein buyer-supplier dyads are engaged. & CORDIS \\
\hline Positional embeddedness & $\begin{array}{l}\text { Bonacich (Bonacich, 1987) eigenvector measure of the network centrality of buyer-supplier } \\
\text { dyads. }\end{array}$ & IHS SupplierBusiness \\
\hline Supplier parks & $\begin{array}{l}\text { (\%) Number of supplier parks wherein a supplier is present/ Total number of supplier parks held } \\
\text { by an automaker }\end{array}$ & IHS SupplierBusiness \& Automotive News \\
\hline Product portfolio & (\%) Number of models produced by a supplier /Total number of automaker's vehicle models & VCA \& IHS SupplierBusiness \\
\hline Supplier segment specialization & Average of automaker's model vehicle weight - Average of supplier's model vehicle weight & VCA \& IHS SupplierBusiness \\
\hline Supplier base & Number of suppliers with which the automaker has procurement relationships & IHS SupplierBusiness \\
\hline Buyer base & Number of automakers with which the supplier has procurement relationships & IHS SupplierBusiness \\
\hline Size (Automaker) & Natural logarithm of automaker's total assets (euros) & Amadeus and Worldscope \\
\hline Size (Supplier) & Natural logarithm of supplier's total assets (euros) & Amadeus and Worldscope \\
\hline
\end{tabular}

Table A2

Descriptive statistics.

\begin{tabular}{|c|c|c|c|c|}
\hline Variables & Mean & SD & Min & Max \\
\hline $\begin{array}{l}\text { Low carbon products } \\
\left(\mathrm{CO}_{2} \text { emissions from passenger cars }\right)\end{array}$ & 193.07 & 34.58 & 132.04 & 296.07 \\
\hline Environmental R\&D cooperation & 0.27 & 0.61 & 0 & 8 \\
\hline Positional embeddedness & 46.63 & 32.26 & 1.15 & 98.22 \\
\hline Supplier parks & 61.10 & 41.98 & 0 & 100 \\
\hline Product portfolio & 63.41 & 32.99 & 8.33 & 100 \\
\hline Supplier segment specialization & -7.92 & 144.85 & -916.11 & 421.07 \\
\hline Supplier base & 252.99 & 53.04 & 59 & 344 \\
\hline \multirow[t]{2}{*}{ Buyer base } & 13.12 & 5.77 & 1 & 24 \\
\hline & 18.34 & 0.75 & 14.53 & 22.01 \\
\hline Buyer base & 15.05 & 2.47 & 1 & 19.55 \\
\hline
\end{tabular}

$\mathrm{N}=1201$ observations. 
Table A3

Correlation matrix.

\begin{tabular}{|c|c|c|c|c|c|c|c|c|c|c|}
\hline Variables & 1 & 2 & 3 & 4 & 5 & 6 & 7 & 8 & 9 & 10 \\
\hline 1. Low-carbon products ( $\mathrm{CO}_{2}$ emissions from passenger cars) & 1.00 & & & & & & & & & \\
\hline 2. Environmental R\&D cooperation & -0.06 & 1.00 & & & & & & & & \\
\hline 3. Positional embeddedness & -0.08 & 0.11 & 1.00 & & & & & & & \\
\hline 4. Supplier parks & -0.13 & 0.04 & 0.38 & 1.00 & & & & & & \\
\hline 5. Product portfolio & 0.04 & 0.03 & 0.57 & 0.55 & 1.00 & & & & & \\
\hline 6. Supplier segment specialization & -0.36 & -0.01 & 0.09 & 0.03 & -0.03 & 1.00 & & & & \\
\hline 7. Supplier base & 0.07 & 0.07 & -0.01 & 0.14 & 0.02 & 0.03 & 1.00 & & & \\
\hline 8. Buyer base & -0.08 & -0.06 & 0.29 & 0.32 & 0.51 & 0.09 & -0.31 & 1.00 & & \\
\hline 9. Size (Automaker) & 0.02 & 0.08 & 0.02 & 0.04 & -0.03 & -0.09 & 0.30 & -0.08 & 1.00 & \\
\hline 10. Size (Supplier) & 0.04 & 0.06 & 0.17 & 0.12 & 0.21 & -0.08 & 0.10 & 0.23 & -0.07 & 1.00 \\
\hline
\end{tabular}

$\mathrm{N}=1201$ observations. Correlations with values in bold are significant at $5 \%$.

Table A4

Ramsey RESET test results.

\begin{tabular}{lll}
\hline Hypothesis & F-statistic & p-value \\
\hline H1a: Environmental R\&D cooperation (linear model) & 2.61 & 0.0704 \\
H1b: Environmental R\&D cooperation (quadratic model) & 2.12 & 0.1210 \\
H2a: Environmental R\&D cooperation \& Positional & 1.36 & 0.2586 \\
$\quad$ embeddedness (linear model) & 1.24 & 0.2898 \\
H2b: Environmental R\&D cooperation (curvilinear effects) & & 0.2398 \\
$\quad$ \& Positional embeddedness & 1.43 & 0.2812 \\
H3a: Environmental R\&D cooperation \& Positional & & \\
$\quad$ embeddedness (curvilinear effects) & 1.27 &
\end{tabular}

\section{References}

Abbasi, M., Nilsson, F., 2012. Themes and challenges in making supply chains en vironmentally sustainable. Supply Chain Manag. Int. J. 17 (5), 517-530. https://doi. org/10.1108/13598541211258582.

Acquaye, A., Genovese, A., Barrett, J., Lenny Koh, S.C., 2014. Benchmarking carbon emissions performance in supply chains'. Supply Chain Manag. Int. J. 19 (3), 306-321. https://doi.org/10.1108/SCM-11-2013-0419.

Agostini, L., Caviggioli, F., 2015. R\&D collaboration in the automotive innovation environment. Manag. Decis. 53 (6), 1224-1246. https://doi.org/10.1108/MD-06-20140407.

Ahuja, G., 2000. The duality of collaboration: inducements and opportunities in the formation of interfirm linkage. Strateg. Manag. J. 21 (3), 317-343.

Ahuja, G., Polidoro, F.J., Mitchell, W., 2009. Structural homophily or social asymmetry? The Formation of alliances by poorly embedded firms. Strateg. Manag. J. 958 (August 2004), 941-958. https://doi.org/10.1002/smj.

Aláez-Aller, R., Longás-García, J.C., 2010. Dynamic supplier management in the automotive industry. Int. J. Oper. Prod. Manag. 30, 312-335. https://doi.org/10.1108/ 01443571011024647.

Albino, V., Dangelico, R.M., Pontrandolfo, P., 2012. Do inter-organizational collaborations enhance a firm's environmental performance? A study of the largest U.S. companies. J. Clean. Prod. 37, 304-315.

Ambrose, E., Marshall, D., Lynch, D., 2010. buyer supplier perspectives on supply chain relationships. Int. J. Oper. Prod. Manag. 30 (12), 1269-1290. https://doi.org/10 1108/01443571011094262.

Ashby, A., Leat, M., Hudson-Smith, M., 2012. Making connections: a review of supply chain management and sustainability literature. Supply Chain Manag. Int. J. 17 (5), 497-516. https://doi.org/10.1108/13598541211258573.

Bai, C., 2012. Evaluating ecological sustainable performance measures for supply chain management. Supply Chain Manag. Int. J. 17 (1), 78-92. https://doi.org/10.1108/ 13598541211212221.

Baum, J. a.C., Calabrese, T., Silverman, B.S., 2000. Don t go it alone: alliance network composition and startups' performance in Canadian biotechnology. Strateg. Manag. J. 21 (3), 267-294. https://doi.org/10.1002/(SICI)1097-0266(200003) $21: 3<267::$ AID-SMJ89 > 3.0.CO;2-8

Becker, W., Dietz, J., 2004. R\&D cooperation and innovation activities of firms-evidence for the German manufacturing industry. Res. Policy 33 (2), 209-223. https://doi.org/ 10.1016/j.respol.2003.07.003

Beers, C. Van, Zand, F., 2013. R\&D cooperation, partner diversity, and innovation performance: an empirical analysis. J. Product. Innov. Manag. 31 (2), 292-312. https:// doi.org/10.1111/jpim.12096.

Belderbos, R., Carree, M., Diederen, B., Lokshin, B., Veugelers, R., 2004. Heterogeneity in R\&D cooperation strategies. Int. J. Ind. Organ. 22 (8-9), 1237-1263. https://doi.org/ 10.1016/j.ijindorg.2004.08.001

Bellamy, M.A., Ghosh, S., Hora, M., 2014. The influence of supply network structure on firm innovation. J. Oper. Manag. 32 (6), 357-373. https://doi.org/10.1016/j.jom. 2014.06.004.

Beske, P., Seuring, S., 2014. Putting sustainability into supply chain management. Supply Chain Manag. Int. J. 19 (3), 322-331. https://doi.org/10.1108/SCM-12-2013-0432.

Birkinshaw, J., Bessant, J., Delbridge, R., 2007. Finding, forming, and performing: creating networks for discontinuous innovation. Calif. Manag. Rev. 49 (3), 67-84.

Bode, C., Wagner, S.M., 2015. Structural drivers of upstream supply chain complexity and the frequency of supply chain disruptions. J. Oper. Manag. 36, 215-228. https://doi. org/10.1016/j.jom.2014.12.004.

Bonacich, P., 1987. Power and centrality: a family of measures. Am. J. Sociol. 92 (5), $1170-1182$.

Borgatti, S.P., Everett, M.G., 1992. Notion of position in social network analysis. Sociol. Methodol. 22, 1-35.

Borgstedt, P., Neyer, B., Schewe, G., 2017. Paving the road to electric vehicles e A patent analysis of the automotive supply industry. J. Clean. Prod. 167, 75-87. https://doi. org/10.1016/j.jclepro.2017.08.161.

Bougrain, F., Haudeville, B., 2002. Innovation, Collaboration and SMEs Internal Research Capacities. Res. Policy 31 (5), 735-747. https://doi.org/10.1016/S0048-7333(01) 00144-5.

Bozarth, C.C., Warsing, D.P., Flynn, B.B., Flynn, E.J., 2009. The impact of supply chain complexity on manufacturing plant performance. J. Oper. Manag. 27 (1), 78-93. https://doi.org/10.1016/j.jom.2008.07.003.

Brandenburg, M., 2016. Supply chain efficiency, value creation and the economic crisis an empirical assessment of the European automotive industry 2002-2010. Int. J. Prod. Econ. 171, 321-335. https://doi.org/10.1016/j.ijpe.2015.07.039.

Breusch, T., Pagan, A., 1980. The Lagrange multiplier test and its applications to model specification in econometrics. Rev. Econ. Stud. 47 (1), 239-253.

Busse, C., Schleper, M.C., Weilenmann, J., Wagner, S.M., 2017. Extending the supply chain visibility boundary - utilizing stakeholders for identifying supply chain sustainability risks. Int. J. Phys. Distrib. Logist. Manag. 47 (1), 18-40. https://doi.org/ 10.1108/SCM-08-2014-0267.

Caner, T., Tyler, B.B., 2015. 'The effects of knowledge depth and scope on the relationship between R\&D alliances and new product development'. J. Product. Innov. Manag. 32 (5), 808-824. https://doi.org/10.1111/jpim.12224.

Caniëls, M.C.J., Gehrsitz, M.H., Semeijn, J., 2013. Participation of suppliers in greening supply chains: an empirical analysis of German automotive suppliers. J. Purch. Supply Manag. 19, 134-143.

Cao, M., Zhang, Q., 2010. Supply chain collaborative advantage: a firm's perspective. Int. J. Prod. Econ. 128 (1), 358-367. https://doi.org/10.1016/j.ijpe.2010.07.037.

Cao, M., Zhang, Q., 2011. Supply chain collaboration: impact on collaborative advantage and firm performance. J. Oper. Manag. 29 (3), 163-180. https://doi.org/10.1016/j. jom.2010.12.008. 
Carnovale, S., Yeniyurt, S., 2015. The role of ego netw ork structure in facilitating ego netw ork innovations. J. Supply Chain Manag. 51 (2).

Carter, C.R., Rogers, D.S., Choi, T.Y., 2015. Toward the theory of the supply chain. J. Supply Chain Manag. 51 (2), 89-97.

Chen, I.J., Paulraj, A., 2004a. Towards a theory of supply chain management: the constructs and measurements. J. Oper. Manag. 22 (2), 119-150. https://doi.org/10. 1016/j.jom.2003.12.007.

Chen, I.J., Paulraj, A., 2004b. Understanding supply chain management: critical research and a theoretical framework. Int. J. Prod. Res. 42 (1), 131-163. https://doi.org/10. 1080/00207540310001602865.

Chiesa, V., Manzini, R., 1998. Organizing for technological collaborations: a managerial perspective. RD Manag. 28 (1996), 199-212. https://doi.org/10.1111/1467-9310. 00096.

Chiou, T.-Y., Hing, K.C., Lettice, F., Chung, S.H., 2011. The influence of greening the suppliers and green innovation on environmental performance and competitive ad vantage in Taiwan. Transp. Res. Part E Logist. Transp. Rev. 47 (6), 822-836.

Choi, T.Y., Dooley, K.J., Rungtusanatham, M., 2001. Supply networks and complex adaptive systems: control versus emergence. J. Oper. Manag. 19 (3), 351-366. https://doi.org/10.1016/S0272-6963(00)00068-1.

Choi, T.Y., Hong, Y., 2002. Unveiling the structure of supply networks: case studies in Honda, Acura, and DaimlerChrysler. J. Oper. Manag. 20 (5), 469-493. https://doi. org/10.1016/S0272-6963(02)00025-6.

Choi, T.Y., Kim, Y., 2008. Structural embeddedness and supplier management: a network perspective. J. Supply Chain Manag. 44 (4), 5-13.

Choi, T.Y., Krause, D.R., 2006. The supply base and its complexity: implications for transaction costs, risks, responsiveness, and innovation. J. Oper. Manag. 24 (5), 637-652. https://doi.org/10.1016/j.jom.2005.07.002.

Choi, T.Y., Wu, Z., 2009. Taking the leap from dyads to triads: buyer - supplier relationships in supply networks. J. Purch. Supply Manag. 15 (4), 263-266. https://doi. org/10.1016/j.pursup.2009.08.003.

Christensen, T.B., 2011. Modularised eco-innovation in the auto industry. J. Clean. Prod. 19 (2-3), 212-220. https://doi.org/10.1016/j.jclepro.2010.09.015.

Coleman, F., Burt, F., 2000. Collaboration networks, structural holes, and innovation: longitudinal study Gautam Ahuja. Adm. Sci. Q. 45, 225-255.

Costantino, N., Pellegrino, R., 2010. Choosing between single and multiple sourcing based on supplier default risk: a real options approach. J. Purch. Supply Manag. 16, 27-40.

Dankbaar, B., 2007. Global sourcing and innovation: the consequences of losing both organizational and geographical proximity. Eur. Plan. Stud. 15 (2), 271-288. https:// doi.org/10.1080/09654310601078812.

Delmas, M., Montiel, I., 2009. Greening the supply chain: when is customer pressure effective? J. Econ. Manag. 18 (1), 171-201. https://doi.org/10.1111/j.1530-9134. 2009.00211.x.

De Marchi, V., 2012. Environmental innovation and R\&D cooperation: empirical evidence from Spanish manufacturing firms. Res. Policy 41 (3), 614-623. https://doi.org/10. 1016/j.respol.2011.10.002.

De Stefano, M.C., Montes-Sancho, M.J., Busch, T., 2016. A natural resource-based view of climate change: innovation challenges in the automobile industry. J. Clean. Prod. 139, 1436-1448. https://doi.org/10.1016/j.jclepro.2016.08.023.

Dietl, H., Royer, S., Stratmann, U., 2009. Value creation architectures and competitive advantage: lessons from the european automobile industry. Calif. Manag. Rev. 51 (3), 24-48 + 3. https://doi.org/10.2307/41166492.

Dijk, M., Orsato, R.J., Kemp, R., 2013. The emergence of an electric mobility trajectory. Energy Policy 52, 135-145. https://doi.org/10.1016/j.enpol.2012.04.024.

Dijk, M., Yarime, M., 2010. Technological Forecasting \& Social Change The emergence of hybrid-electric cars: innovation path creation through co- evolution of supply and demand. Technol. Forecast. Soc. Change 1371-1390. https://doi.org/10.1016/j. techfore.2010.05.001.

Dubois, A., Fredriksson, P., 2008. Cooperating and competing in supply networks: making sense of a triadic sourcing strategy. J. Purch. Supply Manag. 14 (3), 170-179. https:// doi.org/10.1016/j.pursup.2008.05.002.

Dyer, J.H., Singh, H., 1998. The relational view: cooperative strategy and sources of interorganizational competitive advantage. Acad. Manag. Rev. 23 (4), 660. https://doi. org/10.5465/AMR.1998.1255632.

Engau, C., Hoffmann, V.H., 2011. Strategizing in an unpredictable climate: exploring corporate strategies to cope with regulatory uncertainty. Policy Sci. 44 (1), 53-80. https://doi.org/10.1016/j.1rp.2010.11.003.

Everett, M.G., Borgatti, S.P., 1999. The centrality of groups and classes. J. Math. Sociol. 23 (3), 181-201.

Faems, D., Van Looy, B., Debackere, K., 2005. Interorganizational collaboration and innovation: toward a portfolio approach. J. Product. Innov. Manag. 22 (3), 238-250. https://doi.org/10.1111/j.0737-6782.2005.00120.x.

Fawcett, S.E., Magnan, G.M., McCarter, M.W., 2008. Benefits, barriers, and bridges to effective supply chain management. Supply Chain Manag. Int. J. 13 (1), 35-48. https://doi.org/10.1108/13598540810850300.

Fawcett, S.E., McCarter, M.W., Fawcett, A.M., Webb, G.S., Magnan, G.M., 2015. Why supply chain collaboration fails: the socio-structural view of resistance to relationa strategies. Supply Chain Manag. Int. J. 20 (6), 648-663. https://doi.org/10.1108/ SCM-08-2015-0331.

Ford, D., McDowell, R., 1999. Managing business relationships by analyzing the effects and value of different actions. Ind. Mark. Manag. 28, 429-442. https://doi.org/10. 1016/S0019-8501(99)00065-6.

Freeman, L.C., 1978. Centrality in social networks conceptual clarification. Social. Netw. 1 (1968), 215-239.

Fritsch, M., Franke, G., 2004. Innovation, regional knowledge spillovers and R\&D cooperation. Res. Policy 33 (2), 245-255. https://doi.org/10.1016/S0048-7333(03) 00123-9.
Gattiker, T.F., Carter, C.R., 2010. Understanding project champions ability to gain intraorganizational commitment for environmental projects. J. Oper. Manag. 28 (1), $72-85$.

Geffen, C.A., Rothenberg, S., 2000. Suppliers and environmental innovation. Int. J. Oper. Prod. Manag. 20 (2), 166-186. https://doi.org/10.1108/01443570010304242.

Gesing, J., Antons, D., Piening, E.P., Rese, M., Salge, T.O., 2015. Joining forces or going it alone? On the interplay among external collaboration partner types, interfirm governance modes, and internal R\&D. J. Product. Innov. Manag. 32 (3), 424-440. https://doi.org/10.1111/jpim.12227.

Goffin, K., Lemke, F., Szwejczewski, M., 2006. An exploratory study of "close" suppliermanufacturer relationships. J. Oper. Manag. 24 (2), 189-209. https://doi.org/10. 1016/j.jom.2005.05.003.

Golembiewski, B., vom Stein, N., Sick, N., Wiemhöfer, H.D., 2015. Identifying trends in battery technologies with regard to electric mobility: evidence from patenting activities along and across the battery value chain. J. Clean. Prod. 87, 800-810.

Govindan, K., Rajendran, S., Sarkis, J., Murugesan, P., 2015. Multi criteria decision making approaches for green supplier evaluation and selection: a literature review. J. Clean. Prod. 98 (1), 66-83.

Granovetter, M.S., 1973. The strength of weak ties. Am. J. Sociol. 78 (6), 1360-1380.

Granovetter, M.S., 1985. Economic action and social structure: the problem of embeddedness. Am. J. Sociol. 91 (3), 481-510.

Gulati, R., Gargiulo, M., 1999. Where do interorganizational networks come from?'. Am. J. Sociol. 104 (5), 1439-1493.

Hart, S., 1995. 'A natural-resource-based view of the firm. Acad. Manag.Rev. 20 (4), 986. https://doi.org/10.5465/AMR.1995.9512280033.

Hassini, E., Surti, C., Searcy, C., 2012. A literature review and a case study of sustainable supply chains with a focus on metrics. Int. J. Prod. Econ. 140 (1), 69-82. https://doi. org/10.1016/j.ijpe.2012.01.042.

Hausman, J.A., 1978. Specification tests in econometrics. Econometrica 46, 1251-1271.

Hellström, T., 2007. Dimensions of environmentally sustainable innovation: the structure of eco-innovation concepts. Sustain. Dev. 159 (1), 148-159.

Hoetker, G., 2005. How much you know versus how well i know you: selecting a supplier for a technically innovative. Strateg. Manag. J. 26 (1), 75-96. https://doi.org/10. 1002/smj.453.

Hoffmann, V.H., Trautmann, T., Hamprecht, J., 2009. Regulatory uncertainty: a reason to postpone investments? Not necessarily. J. Manag. Stud. 46 (7), 1227-1253.

Hottenrott, H., Lopes-Bento, C., 2016. 'R\&D partnerships and innovation performance: can there be too much of a good thing? J. Product. Innov. Manag. 33 (6), 773-794.

Jasiński, D., Meredith, J., Kirwan, K., 2016. A comprehensive framework for automotive sustainability assessment. J. Clean. Prod. 135, 1034-1044. https://doi.org/10.1016/ j.jclepro.2016.07.027.

Jayaraman, V., Klassen, R., Linton, J.D., 2007. Supply chain management in a sustainable environment. J. Oper. Manag. 25 (6), 1071-1074.

Johnsen, T.E., 2011. Supply network delegation and intervention strategies during supplier involvement in new product development. Int. J. Oper. Prod. Manag. 31 (6), 686-708.

Kavusan, K., Noorderhaven, N.G., Duysters, G.M., 2016. Knowledge acquisition and complementary specialization in alliances: the impact of technological overlap and alliance experience. Res. Policy 2153-2165. https://doi.org/10.1016/j.respol.2016. 09.013.

Kim, Y., Choi, T.Y., Yan, T., Dooley, K., 2011. Structural investigation of supply networks: a social network analysis approach. J. Op. Manag. 194-211. https://doi.org/10. 1016/j.jom.2010.11.001.

Klassen, R.D., Vachon, S., 2003. Collaboration and evaluation in the supply chain: the impact on plant-level environmental investment. Prod. Oper. Manag. 12 (3), 336-352. https://doi.org/10.1111/j.1937-5956.2003.tb00207.x.

Kleinknecht, A., Reijnen, J.O.N., 1992. Why do firms cooperate on R\&D? An empirical study. Res. Policy 21 (4), 347-360. https://doi.org/10.1016/0048-7333(92)90033-Z.

Kotabe, M., Martin, X., Domoto, H., 2003. Gaining from vertical partnerships: knowledge transfer, relationship duration, and supplier performance improvement in the U.S. and Japanese automotive industries. Strateg. Manag. J. 24 (4), 293-316.

Kotabe, M., Swan, K.S., 1995. The role of strategic alliances in high-technology new product development. Strateg. Manag. J. 16 (8), 621-636.

Koufteros, X.A., Cheng, T.C.E., Lai, K.H., 2007. "Black-box" and "gray-box" supplier integration in product development: antecedents, consequences and the moderating role of firm size. J. Oper. Manag. 25 (4), 847-870.

KPMG, 2010. The Transformation of the Automotive Industry: The Environmental Regulation Effect.

Lee, K.H., 2011. Integrating carbon footprint into supply chain management: the case of Hyundai Motor Company (HMC) in the automobile industry'. J. Clean. Prod. 19 (11), 1216-1223. https://doi.org/10.1016/j.jclepro.2011.03.010.

Lee, T.-H., White, H., Granger, C.W.J., 1993. Testing for neglected nonlinearity in time series models. A comparison of neural network methods and alternative tests. J. Econ. 56, 269-290.

Leohold, J. Hodac, I., 2009. The Automotive Industry Focus on Future R\&D Challenges.

Lettice, F., Wyatt, C., Evans, S., 2010. Buyer-supplier partnerships during product design and development in the global automotive sector: who invests, in what and when? Int. J. Prod. Econ. 127 (2), 309-319. https://doi.org/10.1016/j.ijpe.2009.08.007.

Levy, D.L.,Rothenberg, S. 2002. Heterogeneity and change in environmental strategy: Technological and political responses to climate change in the automobile industry. In: Hoffman, M. (Eds), Organizations, Policy and the Natural Environment. Stanford.

Lii, P., Kuo, F.I., 2016. Innovation-oriented supply chain integration for combined competitiveness and firm performance. Int. J. Prod. Econ. 174, 142-155. https://doi.org/ 10.1016/j.ijpe.2016.01.018.

Lin, C., Wu, Y., Chang, C., Wang, W., Lee, C., 2012. The alliance innovation performance of R\&D alliances: the absorptive capacity perspective. Technovation 32 . Elsevier, pp. 
282-292. https://doi.org/10.1016/j.technovation.2012.01.004.

Magnusson, T., Berggren, C., 2001. Environmental innovation in auto development managing technological uncertainty within strict time limits. Int. J. Veh. Des. 26 (2-3), 101-114.

Meinlschmidt, J., Foerstl, K., Kirchoff, J.F., 2016. The role of absorptive and desorptive capacity (ACDC) in sustainable supply management. Int. J. Phys. Distrib. Logist. Manag. 46 (2), 177-211. https://doi.org/10.1108/IJPDLM-05-2015-0138.

Min, S., Roath, A., Daugherty, P.J., Genchev, S.E., Chen, H., Arndt, A.D., 2005. Supply chain collaboration: what's happening? Int. J. Logist. Manag. 16 (2), 237-256.

Minin, A. Di, Frattini, F., Piccaluga, A., 2010. Fiat: open innovation in a downturn (1993-2003). Calif. Manag. Rev. 52 (3), 132-159.

Miotti, L., Sachwald, F., 2003. Co-operative R\&D: why and with whom? An integrated framework of analysis. Res. Policy 32 (8), 1481-1499. https://doi.org/10.1016/ S0048-7333(02)00159-2.

Morgan, L.O., Daniels, R.L., 2001. Integrating product mix and technology adoption decisions: a portfolio approach for evaluating advanced technologies in the automobile industry. J. Oper. Manag. 19, 219-238.

Morrison, A., Lynch, P., Johns, N., Morrison, A., Lynch, P., Johns, N., 2004. International tourism networks. Int. J. Contemp. Hosp. Manag. 16 (3), 197-202. https://doi.org/ $10.1108 / 09596110410531195$.

Munksgaard, K.B., 2010. Exploring perceptions of interdependencies: strategic options in supplier-customer relationships. Ind. Mark. Manag. 39 (6), 936-946. https://doi.org/ 10.1016/j.indmarman.2010.06.013.

Nair, A., Blome, C., Choi, T.Y., Lee, G., 2018. Re-visiting collaborative behavior in supply networks: structural embeddedness and the influence of contextual changes and sanctions. J. Purch. Supply Manag. 24 (2), 135-150. https://doi.org/10.1016/j. pursup.2017.11.006.

Nair, A., Yan, T., Ro, Y.K., Oke, A., Chiles, T.H., Lee, S.-Y., 2016. How environmental innovations emerge and proliferate in supply networks: a complex adaptive systems perspective. J. Supply Chain Manag. 52 (2), 66-86.

Nooteboom, B., Haverbeke, W. Van, Duysters, G., Gilsing, V., Oord, A. Van Den, 2007. Optimal cognitive distance and absorptive capacity. Res. Policy 36, 1016-1034. https://doi.org/10.1016/j.respol.2007.04.003.

Nyaga, G.N., Whipple, J.M., Lynch, D.F., 2010. Examining supply chain relationships: do buyer and supplier perspectives on collaborative relationships differ? J. Oper. Manag. 28 (2), 101-114. https://doi.org/10.1016/j.jom.2009.07.005.

Oh, J., Rhee, S.-K., 2008. The influence of supplier capabilities and technology uncertainty on manufacturer-supplier collaboration: a study of the Korean automotive industry. Int. J. Oper. Prod. Manag. 28 (6), 490-517. https://doi.org/10.1108/ 01443570810875331.

Oxley, J.E., Sampson, R.C., 2004. The scope and governance of international R\&D alliances. Strateg. Manag. J. 749, 723-749. https://doi.org/10.1002/smj.391.

Pagell, M., Krumwiede, D.W., Sheu, C., 2007. Efficacy of environmental and supplier relationship investments - moderating effects of external environment. Int. J. Prod. Res. 45 (9), 2005-2028. https://doi.org/10.1080/00207540600634931.

Pagell, M., Wu, Z.H., 2009. Building a more complete theory of sustainable supply chain management using case studies of 10 exemplars. J. Supply Chain Manag. 45 (2), 37-56. https://doi.org/10.1111/j.1745-493X.2009.03162.x.

Pagell, M., Wu, Z., Wasserman, M.E., 2010. Thinking differently about purchasing portfolios: an assessment of sustainable sourcing. J. Supply Chain Manag. 46 (1), 57-73. https://doi.org/10.1111/j.1745-493X.2009.03186.x.

Pathak, S., Wu, Z., Johnston, D., 2014. Toward a structural view of co-opetition in supply networks. J. Oper. Manag. 32 (5), 254-267.

Paulraj, A., 2011. Understanding the relationships between internal resources and capabilities, sustainable supply management and organizational sustainability. J. Supply Chain Manag. 47 (1), 19-37. https://doi.org/10.1111/j.1745-493X.2010.03212.x.

Paulraj, A., Lado, A.A., Chen, I.J., 2008. Inter-organizational communication as a relational competency: antecedents and performance outcomes in collaborative buyer-supplier relationships. J. Oper. Manag. 26 (1), 45-64. https://doi.org/10.1016/j.jom. 2007.04.001.

Penna, C.C.R., Geels, F.W., 2015. Climate change and the slow reorientation of the American car industry ( 1979 - 2012): an application and extension of the Dialectic Issue LifeCycle ( DILC) model. Res. Policy 44 (5), 1029-1048. https://doi.org/10. 1016/j.respol.2014.11.010.

Pfohl, H.-C., Gareis, K., 2005. Supplier parks in the German automotive industry: a critical comparison with similar concepts. J. Phys. Distrib. Logist. Manag. 35 (5), 302-317. https://doi.org/10.1108/13598540410527024.

Pinkse, J., Kolk, A., 2010. Challenges and Trade-Offs in Corporate Innovation for Climate Change. Bus. Strategy Environ. 272 (March), 261-272.

Pisano, G.P., 1990. The R\&D boundaries of the firm: an empirical analysis. Adm. Sci. Q. 35 (March), 153-176.

Polidoro, F., Ahuja, G., Mitchell, W., Jr, F.P., 2011. When the socialstructure overshadows competitive incentives: the effect of network embeddedness on joint venture dissolution. Acad. Manag. J. 54 (1), 203-223.

Powell, W.W., Koput, K.W., Smith-doerr, L., 1996. Interorganizational and the collaboration locus of Innovation: networks of learning in biotechnology. Adm. Sci. Q. 41 (1), 116-145.

PricewaterhouseCoopers 2007. The automotive industry and climate change. Framework and dynamics of the $\mathrm{CO}_{2}$ (r)evolution. Stuttgart.

Puko, T., Spector, M. Chester, Dawson, 2018. EPA Will Ease Vehicle-Emissions Standards, The Wall Streat Journal, April 2. Available at: 〈https://www.wsj.com/articles/epawill-ease-vehicle-emissions-standards-1522697013〉.

Ragatz, G.L., Handfield, R.B., Petersen, K.J., 2002. Benefits associated with supplier integration into new product development under conditions of technology uncertainty. J. Bus. Res. 55, 389-400. https://doi.org/10.1016/S0148-2963(00)00158-2.

Revilla, E., Villena, V.H., 2012. Knowledge integration taxonomy in buyer-supplier relationships: trade-offs betw een efficiency and innovation. Int. J. Prod. Econ. 140 (2), 854-864. https://doi.org/10.1016/j.ijpe.2012.07.002.

Robertson, T.S., Gatignon, H., 1998. Technology development mode: a transaction cost conceptualization. Strateg. Manag. J. 19 (6), 515-531. https://doi.org/10.1002/ (SICI)1097-0266(199806)19:6 < 515::AID-SMJ960 > 3.0.CO;2-F.

Rodriguez Lopez, J.M., Sakhel, A., Busch, T., 2017. Corporate investments and environmental regulation: the role of regulatory uncertainty, regulation-induced uncertainty, and investment history'. Eur. Manag. J. 35. pp. 91-101. https://doi.org/10.1016/j. emj.2016.06.004.

Roscoe, S., Cousins, P.D., Lamming, R.C., 2016. Developing eco-innovations: a three-stage typology of supply networks. J. Clean. Prod. 112. pp. 1948-1959. https://doi.org/10. 1016/j.jclepro.2015.06.125.

Roseira, C., Brito, C., Henneberg, S.C., 2010. Managing interdependencies in supplier networks. Ind. Mark. Manag. 39 (6), 925-935. https://doi.org/10.1016/j. indmarman.2010.06.012.

Rothenberg, S., Ettlie, J.E., 2011. Strategies to cope with regulatory uncertainty in the auto industry. Calif. Manag. Rev. 54 (1), 126-144. https://doi.org/10.1525/cmr. 2011.54.1.126.

Rothenberg, S., Levy, D.L., 2012. Corporate perceptions of climate science: the role of corporate environmental scientists. Bus. Soc. 51 (1), 31-61. https://doi.org/10. $1177 / 0007650311427424$.

Santamaria, L., Surroca, J., 2011. Matching the goals and impacts of R\&D collaboration. Eur. Manag. Rev. 8 (2), 95-109. https://doi.org/10.1111/j.1740-4762.2011. 01012.x.

Sawhney, M., Zabin, J., 2002. Managing and measuring relational equity. J. Acad. Mark. Sci. 30 (4), 313-332.

Seuring, S., Müller, M., 2008. From a literature review to a conceptual framework for sustainable supply chain management. J. Clean. Prod. 16 (15), 1699-1710. https:// doi.org/10.1016/j.jclepro.2008.04.020.

Shing, K., 1997. The impact of technological complexity and interfirm cooperation on business survival. Acad. Manag. J. 40 (2), 339-367.

Sierzchula, W., Bakker, S., Maat, K., van Wee, B., 2012. Technological diversity of emerging eco-innovations: a case study of the automobile industry. J. Clean. Prod. 37, 211-220.

Simatupang, T.M., Sridharan, R., 2002. The collaborative supply chain. Int. J. Logist. Manag. 13 (1), 15-30. https://doi.org/10.1108/09574090210806333.

Simpson, D., 2010. Use of supply relationships to recycle secondary materials. Int. J. Prod. Res. 48 (1), 227-249. https://doi.org/10.1080/00207540802415584.

Simpson, D., Power, D., Samson, D., 2007. Greening the automotive supply chain: a relationship perspective. Int. J. Oper. Prod. Manag. 27 (1), 28-48. https://doi.org/10 1108/01443570710714529.

Singh, K., 1997. The impact of technological complexity and interfirm cooperation on business survival. Acad. Manag. J. 40 (2), 339-367. https://doi.org/10.5465/ AMBPP.1995.17536285.

Song, M., Di Benedetto, C.A., 2008. Supplier's involvement and success of radical new product development in new ventures. J. Oper. Manag. 26 (1), 1-22.

Stock, G.N., Tatikonda, M.V., 2000. A typology of project-level technology transfer processes. J. Oper. Manag. 18 (6), 719-737.

Stucki, T. Woerter, M., 2012. Determinants of Green Innovation: The Impact of Internal and External Knowledge. KoF Working Paper n.314. https://papers.ssrn.com/sol3/ papers.cfm?abstract id $=2151800$.

Tachizawa, E.M., Wong, C.Y., 2015. The performance of green supply chain management governance mechanisms: a supply network and complexity perspective. J. Supply Chain Manag. 51 (3), 18-32. https://doi.org/10.1111/jscm.12072.

Takeishi, A., 2001. Bridging inter- and intra-firm boundaries: management of supplier involvement in automobile product development. Strateg. Manag. J. 22 (5), 403-433. https://doi.org/10.1002/smj.164.

Tate, W.L., Ellram, L.M., Gölgeci, I., 2013. Diffusion of environmental business practices: a network approach. J. Purch. Supply Manag. 19 (4), 264-275. https://doi.org/10. 1016/j.pursup.2013.08.001.

Taticchi, P., Tonelli, F., Pasqualino, R., 2013. Performance measurement of sustainable supply chains. Int. J. Product. Perform. Manag. 62 (8), 782-804. https://doi.org/10. 1108/IJPPM-03-2013-0037.

Teece, D.J., 1992. Competition, cooperation, and innovation: Organizational arrangements for regimes of rapid technological progress. J. Econ. Behav. Organ. 18 (1), 1-25. https://doi.org/10.1016/0167-2681(92)90050-L.

Touboulic, A., Walker, H., 2015. Love me, love me not: a nuanced view on collaboration in sustainable supply chains. J. Purch. Supply Manag. 21 (3), 178-191. https://doi. org/10.1016/j.pursup.2015.05.001.

Tushman, M.L., Anderson, P., 1986. Technological discontinuities and organizational environments. Adm. Sci. Q. 31 (3), 439-465.

Un, C.A., Asakawa, K., 2015. Types of R\&D collaborations and process innovation: the benefit of collaborating upstream in the knowledge chain. J. Product. Innov. Manag. 32 (1), 138-153. https://doi.org/10.1111/jpim.12229.

Uzzi, B., 1997. Social structure and competition in interfirm networks: the paradox of embeddedness. Adm. Sci. Q. 42 (1), 35-67.

Vachon, S., Klassen, R.D., 2006a. 'Extending green practices across the supply chain. The impact of upstream and downstream integration. Int. J. Oper. Prod. Manag. 26 (7), 795-821.

Vachon, S., Klassen, R.D., 2006b. Green project partnership in the supply chain: the case of the package printing industry. J. Clean. Prod. 14 (6-7), 661-671. https://doi.org/ 10.1016/j.jclepro.2005.07.014.

Vachon, S., Klassen, R.D., 2007. Supply chain management and environmental technologies: the role of integration. Int. J. Prod. Res. 45 (2), 401-423. https://doi.org/10. 1080/00207540600597781.

Vachon, S., Klassen, R.D., 2008. Environmental management and manufacturing 
performance: the role of collaboration in the supply chain. Int. J. Prod. Econ. 111 (2), 299-315. https://doi.org/10.1016/j.ijpe.2006.11.030.

Vasudeva, G., Anand, J., 2011. Unpacking absorptive capacity: a study of knowledge utilization from alliance portfolios. Acad. Manag. J. 54 (3), 611-623.

Vurro, C., Russo, A., Perrini, F., 2009. Shaping sustainable value chains: network determinants of supply chain governance models. J. Bus. Ethics 90 (SUPPL. 4) 607-621. https://doi.org/10.1007/s10551-010-0595-x.

Wagner, S., Johnson, J., 2004. Configuring and managing strategic supplier portfolios. Ind. Mark. Manag. 33 (8), 717-730.

Wang, Y., Li-ying, J., 2015. Licensing foreign technology and the moderating role of local R \& D collaboration: extending the relational view. J. Prod. 32 (6), 997-1013. https://doi.org/10.1111/jpim.12246.

Whipple, J.M., Wiedmer, R., Boyer, K.K., 2015. A dyadic investigation of collaborative competence, social capital, and performance in buyer-supplier relationships. J. Supply Chain Manag. 51 (2), 3-21. https://doi.org/10.1111/jscm.12071.

Wilhelm, M.M., 2011. Managing coopetition through horizontal supply chain relations: linking dyadic and network levels of analysis. J. Oper. Manag. 29 (7-8), 663-676. https://doi.org/10.1016/j.jom.2011.03.003.

Wong, C.Y., Boon-itt, S., Wong, C.W.Y., 2011. The contingency effects of environmenta uncertainty on the relationship between supply chain integration and operational performance. J. Oper. Manag. 29 (6), 604-615.

Wu, Z., Choi, T.Y., Rungtusanatham, M.J., 2010. Supplier-supplier relationships in buyer-supplier-supplier triads: Implications for supplier performance. J. Oper. Manag. 28 (2), 115-123.

Yeniyurt, S., Townsend, J.D., Cavusgil, S.T., Ghauri, P.N., 2009. Mimetic and experiential effects in international marketing alliance formations of US pharmaceuticals firms: an event history analysis. J. Int. Bus. Stud. 40, 301-320. https://doi.org/10.1057/jibs. 2008.62 .

Zacharia, Z.G., Nix, N.W., Lusch, R.F., 2011. Capabilities that enhance outcomes of an episodic supply chain collaboration. J. Oper. Manag. 29 (6), 591-603. https://doi org/10.1016/j.jom.2011.02.001.

Zapata, C., Nieuwenhuis, P., 2010. Exploring innovation in the automotive industry: new technologies for cleaner cars. J. Clean. Prod. 18 (1), 14-20. https://doi.org/10.1016/ j.jclepro.2009.09.009. 